NBER WORKING PAPER SERIES

\title{
HEIGHTS AND HUMAN WELFARE: RECENT DEVELOPMENTS AND NEW DIRECTIONS
}

\author{
Richard H. Steckel \\ Working Paper 14536 \\ http://www.nber.org/papers/w14536

\section{NATIONAL BUREAU OF ECONOMIC RESEARCH 1050 Massachusetts Avenue Cambridge, MA 02138} \\ December 2008
}

The author thanks Joerg Baten, Scott Carson, Dora Costa, Angus Deaton, John Komlos, Tim Leunig, Marco Sunder, and Joachim Voth for comments and suggestions. The views expressed herein are those of the author(s) and do not necessarily reflect the views of the National Bureau of Economic Research.

NBER working papers are circulated for discussion and comment purposes. They have not been peerreviewed or been subject to the review by the NBER Board of Directors that accompanies official NBER publications.

(C) 2008 by Richard H. Steckel. All rights reserved. Short sections of text, not to exceed two paragraphs, may be quoted without explicit permission provided that full credit, including $\odot$ notice, is given to the source. 
Heights and Human Welfare: Recent Developments and New Directions

Richard H. Steckel

NBER Working Paper No. 14536

December 2008, Revised January 2009

JEL No. N00,O1

\begin{abstract}
$\underline{\text { ABSTRACT }}$
Since 1995 approximately 325 publications on stature have appeared in the social sciences, which is more than a four-fold increase in the rate of production relative to the period 1977-1994. The expansion occurred in several areas, but especially within economics, indicating that heights are now widely accepted as a useful measure of human welfare. Much of this new work extends beyond the traditional bailiwick of anthropometric history, including biological welfare during economic and political crises; anthropometric influences on wages; the welfare of women relative to men in the contemporary world; the fetal origins hypothesis; and inequality in the developing world. The approach has also expanded within economic history to consider the consequences of empire for colonials; the health of populations lacking traditional measures of social performance; the consequences of smallpox; and very long-term trends in health. Much has also been learned about socioeconomic aspects of inequality, the welfare implications of industrialization, and socioeconomic determinants of stature. The last is a work in progress and one may doubt whether sufficient longitudinal evidence will become available for a complete understanding of the variety and strength of pathways that affect human physical growth.
\end{abstract}

\author{
Richard H. Steckel \\ Department of Economics \\ Ohio State University \\ 410 Arps Hall, 1945 North High Street \\ Columbus, OH 43210-1172 \\ and NBER \\ steckel.1@osu.edu
}


In the late 1970s researchers began to create the new anthropometric history, which required interdisciplinary communication and clear applications to a critical mass of historical problems in which there was an established interest (Steckel 1998). Thirty years ago most social scientists had little understanding of biological or socioeconomic influences on human physical growth, and similarly human biologists understood little economics or history. Influential papers using anthropometric data for an audience of economic historians drew upon the literature of human biology to explain what average heights do (and do not) measure and then applied concepts to specific research questions. The initial findings stimulated further research, and the field has mushroomed over the past three decades because heights capture important aspects of human welfare, and abundant historical and contemporary records give wide scope to research interests.

My previous survey discussed the literature from the late 1970s to 1994 (Steckel 1995b) and here I extend the effort from 1995 to the present while placing the articles of this special issue in context. The review largely excludes publications catering to audiences of public health, medicine, epidemiology, and medical anthropology, for which the literature is enormous but of tangential interest to most readers of this journal. I include articles from human biology journals if they discuss history but omit most working papers in all fields because the published work is already extensive. Therefore it is useful to organize the main body of material under subject headings arranged alphabetically, much like an encyclopedia.

\section{Research Trends}

My 1995 article included 145 references, of which 83 were height studies as opposed to publications that placed this body of work in context. At a rate of about 5 publications per year from the late 1970s to 1994, the majority of these covered topics in economic history (53) or economic development (12). ${ }^{1}$ In contrast, this review cites 326 studies (including 14 books) that interpret or otherwise use heights published from 1995 through 2008, for a rate of 23.3 publications per year. Even for someone 
reasonably well acquainted with the literature, the large increase in the rate is surprising. The surge, which only an extensive literature search could reveal, reflects the proliferation of height research on many topics in numerous subfields of economics and in other segments of the social sciences. My earlier review found four articles that analyzed or substantially used heights, for example, in the top four journals in economics, but since 1995 these journals have published 13 papers, including nine in the American Economic Review (of which three were in Papers and Proceedings), three in the Journal of Political Economy and one in the Quarterly Journal of Economics. In the earlier review there were only four height publications in specialty economics journals, but here I found 51 articles of this type, in 25 outlets ranging from the Economic Journal to the Journal of Econometrics, the Journal of Economic Perspectives, Agricultural Economics, and Economic Development and Cultural Change.

Our profession's pattern of specialization may explain the surprise. Most scholars acquire expertise in particular research areas such as technological change, inequality, globalization, or the economic performance of a particular country, as opposed to a technique such as anthropometrics. Because of their versatility, heights are applied in numerous fields and subfields, which remain largely unfamiliar to most researchers. Given our research strategies I suspect that few if any researchers are acquainted, on an ongoing basis, with all the literature that uses or interprets heights in the social sciences. Once concentrated on slavery, inequality, industrialization and mortality, now the historical height literature also embraces the effects of colonialism; the health and well-being of coal miners; the treatment of men versus women; the consequences of small pox; the health of Native Americans; the health effects of economic and political crises, and so forth. An enormous expansion of height research has occurred in the area of economic development, and height data are increasingly used in studying contemporary economic and social problems. Below I provide brief research summaries for each of these areas.

With regard to the most popular outlets for height research, the economic history journals ranked first prior to 1995 (18 articles out of 83 , or $21.7 \%$ of the total); the 
interdisciplinary history journals were second (10 articles or 12.0\%); and a smattering found homes in non-blue ribbon general interest economics journals (3) or outlets catering to economic development (3). Many publications appeared in edited collections (10) or human biology journals (8). None appeared in journals intended primarily for demographers and only one for historians employed by history departments.

In the current review, economic history journals retain their numerical lead with 72 of 326 articles $(22.1 \%)$ concentrated in the Economic History Review (19), the Journal of Economic History (18), and Explorations in Economic History (16, including eight in this special issue), followed by the European Review of Economic History (6) and Research in Economic History (5). Interdisciplinary history journals contributed 25 papers $(7.7 \%)$, and other journals written for an audience of economists provided 51 articles $(15.7 \%)$ of which28 appeared in development outlets. As height research has become more widely accepted, the relative (but not the absolute number) of publications has declined in interdisciplinary history journals.

With 65 articles, Economics and Human Biology is the largest single outlet for height research. First appearing in 2003, one might think this journal alone was the source of the large upswing in height publications. This is not the case, however. Even if all its height articles were removed from consideration, and under the unlikely assumption this research would not have appeared elsewhere, the annual rate of height publications since 1995 would decline by only 4.6 articles per year (from 23.3 to 18.7), which is still more than three times the rate from the late 1970s to 1994 . Therefore this new and useful journal reflects a trend, rather than the cause of growing interest in anthropometric research.

Although many historians read the interdisciplinary history journals, the mainstream history journals in the United States publish few studies that make substantial use of heights. One was cited in the 1995 review and here I found only three, two in the American Historical Review and one in the William and Mary Quarterly, although it is likely that others not cited here appear in French, German, Spanish or other language publications. Also puzzling is the absence of height studies published in 
mainline political science or sociology journals. Given the interest in inequality and class differences in social performance within these subject areas, one would think the methodology would appeal to these audiences. There is certainly no lack of modern surveys that contain height data useful in studying these questions, which suggests that anthropometric historians should undertake some useful missionary work in these fields. Similarly, it is perplexing that demographers have made relatively little use of heights, or at least the mainline journals in the field contain few articles. The 1995 review cites none from these outlets and here I found only four articles, three in Demography and one in Population Studies. Because the articles were written with little discussion of the methodology of height research, one can presume the audiences are at least somewhat acquainted with the height literature. Apparently, however, few researchers in demography or history analyze heights as part of their own research programs. One wonders whether they teach the anthropometric approach in their classes.

Psychologists have made some use of stature, but mostly to consider how individuals feel about their own height (see discussion and citations in (Hall 2006)). As the cognitive consequences of early childhood nutritional deprivation have become more widely understood, psychologists who analyze measures of cognitive achievement have made increasing use of heights, especially measurements in early childhood (see for example, the discussion and references in (Heckman 2006)).

Height studies are now more international in character. In the early years of the field, most of the historical papers featured topics about the United States or Western Europe, while a sprinkling covered developing countries such as India or the Philippines. The current review considers 225 height studies that have a clear geographic focus and among these the United States (21.3\%) and Northwest Europe $(30.7 \%)$ continue to dominate, but a substantial number of publications also appear for Southern Europe (6.2\%); Eastern Europe and Russia (8.0\%); South America (10.2\%); Africa (8.0\%); and Asia (11.6\%). In this spirit, the special issue reflects the current global nature of the field, with two papers on England and one each on Argentina, China, the Middle East, Russia and the United States (Carson 2009; Horrell, Meredith et 
al. 2009; Humphries and Leunig 2009b; Morgan 2009; Salvatore 2009; Stegl and Baten 2009; Wheatcroft 2009).

The geographic blend of height papers reflects a growing interest and greater data availability in developing countries. Like the recent past of countries in Southern Europe or Eastern Europe and Russia, where height studies have proliferated, many developing countries have weak or unreliable measures of social performance with which to investigate geographic patterns, chronological trends and policy questions. In these countries heights are often plentiful from military records or modern surveys. Moreover, heights are reasonably comparable over time and space, or at least more reliable and comparable than many traditional social statistics, especially for countries bedeviled by high rates of inflation, which complicate measures of real income or real wages, or large informal sectors that are missed by national income accounts. In addition, many development problems are seen through the lenses of malnutrition, poor education, high rates of exposure to pathogens, and poor public health services. In these environments, heights are a sensitive indicator of child health useful for monitoring policy interventions.

Lastly, since the mid 1990s the popular press and the news media have shown considerable interest in height studies, including a recent book on ways that stature affects the health and happiness of boys (Hall 2006). Articles written for an audience of professionals, but not necessarily specialists in economics, appeared in Challenge; Indicators: The Journal of Social Health; Historical Statistics of the United States: Millennial Edition; and The Journal of Economic Perspectives (Steckel 1995a; Steckel 2003a; Steckel 2006; Steckel 2008). The October 16, 1996 issue of TIME magazine (European and Asian editions) featured a cover story on height research, emphasizing the importance of stature as a measure of human welfare. The New York Times has published several pieces: November 5, 2006 (book review); March 1, 2005 (science section); and October 29, 2002 (science section). Feature stories on height research appeared in the April 5, 2004 issue of The New Yorker and in the March 31, 2005 issue of the Canadian publication Macleans. The Spring 2004 issue of the Newsletter of the Cliometric Society noted that more than two dozen popular press and website articles 
on height research appeared in the 6 months prior to publication, including those in the Sidney Morning Herald, BBC News, Le Monde, Suddeutsche Zeitung, and Pressetext Austria.

There are many ways to organize the material of any substantial literature review. Because heights are a versatile measure of social performance with applications to numerous research questions, here I use fifteen broad subjects, discussed in alphabetical order: (1) colonialism; (2) controversies and disputes; (3) convergence; (4) crises in social performance; (5) determinants of heights; (6) development; (7) fetal origins hypothesis; (8) gender; (9) health and economic growth; (10) industrialization; (11) inequality; (12) living standards; (13) long-term trends; (14) methods; and (15) wages. Numerous papers overlap with two or more categories, which I identify where relevant.

\section{Colonialism}

One of the new applications of height research concerns the welfare of populations that lived under colonial rule. Over the past decade papers have appeared on India, North America, and Burma under the British, and Taiwan under the Japanese (Brennan, McDonald et al. 1997; Komlos 2001; Olds 2003; Morgan and Liu 2007; Bassino and Coclanis 2008). Various working papers in this general area are underway for other countries. The results suggest that colonialism, often maligned as exploitative, had some positive welfare benefit at least in these countries. Brennan et al. report a modest increase in the average heights in India under the British, but suggest this might be attributed to greater engagement in world markets and expansion of the transportation system. With regard to Taiwan, Olds finds that heights of children improved under Japanese rule up to 1930, which squares with results of Morgan and Liu. Unlike Olds, the latter have evidence through 1945, which indicates that heights after 1930 were static, as they were in Japan. In Burma the picture is more pessimistic; heights did increase after World War II but this was apparently a recovery from an earlier height decline induced by land-clearing for rice cultivation in malaria-infested areas. 
Komlos assembled evidence on heights from newspaper advertisements on American-born soldiers who deserted and on run-away apprentices (Komlos 2001), reporting a 0.5 inch decline in the first half of the eighteenth century followed by a substantial rise. By the end of the century American men were as much as 6.6 centimeters taller than the English and at age 16 the American apprentices were about 12 centimeters taller than poor children of London. If the British exploited the American colony, then other factors such as abundant cheap land and low population density more than compensated.

\section{Controversies}

Enduring debates in economic history often involve topics for which there is at least some traditional evidence on social performance such as Gross Domestic Product, technological change, wages, wealth, or life expectancy. Consider, for example, the course of human welfare during industrialization, the relationship between inequality and economic growth or the contribution of technological change to rising incomes. Although a few detractors continue to believe that anthropometric history is "not economics," heights are advancing toward the status of traditional evidence in economics. As proof, the most recent papers discussing heights in various economics journals seldom, or at most briefly, discuss the methodology of height research (see, for example, (Stillman and Thomas 2008)). Numerous controversies accompany the new role, and this section includes debates or exchanges among scholars over numerous subjects involving height research. No doubt the number of publications in this category, which is already large and here organized under seven subheadings, will continue to grow over time. Therefore it is useful to reflect on the various debates and to consider additional research that would advance the field.

Coal mining. Primarily using data gathered by the Children's Employment Commission in 1841, Peter Kirby observes that children who worked in English coal mines tended to be 1 to 3 inches shorter than children who worked in other jobs, depending upon age and occupation (Kirby 1995). Specifically, he constructs a scatter 
diagram of height by age, which shows that colliers were systematically smaller than children who worked on farms. Given that diets seem to have been good and the children were reasonably robust, he attributes short stature to lack of sunlight, which caused rickets and bowed long bones, and to genetic selection by fathers into an occupation where short stature was an advantage for working narrow coal seams. Humphries challenges his assessment of health as dubious, arguing that the experience of colliers is not a counter-example to anthropometric history, which takes stature as a good index of health and human welfare (Humphries 1997). She notes that a disproportionate number of colliers came from disadvantaged families and that coalmining was hard work, which drained nutritional intake. Moreover wives of coalminers usually worked outside the home and were thus unable to breastfeed their young children, which often resulted in diarrheal diseases arising from contaminated supplements. In a reply Kirby indicates that he was misunderstood, affirming that heights are a good measure of human welfare (Kirby 1997). In defense of occupational selection by height, he notes that short children tended to work in mines with narrow seams.

As an outsider to this lively exchange over the effects of mining on health, I see an opportunity to advance the discussion by obtaining evidence on the prevalence of rickets among colliery children and the effect of rickets on stature. Perhaps much or most of the height deficit is related to this specific disease, although one might think that respiratory infections attributable to life in the mines were also relevant for height.

Native Americans. Depictions of Native American life are arguably the most distorted and contradictory of any large ethnic group in American history. Several centuries ago, accounts of early explorers and missionaries merged with the primitivistic tradition of Western civilization to create an image of the noble savage, who inhabited an ideal landscape and lived in harmony with nature and reason (Berkhofer 1988). During the westward movement the natives became bad Indians, who then morphed into entertainers in Wild Bill Cody's western shows. A few decades later western 
movies caricatured their habits and by the end of the twentieth century many intellectuals saw aborigines as victims of Euro-American aggression.

Height data collected by Franz Boas and his assistants near the end of the century shed light on the health of Plains tribes who occupied a vast swath of land from northern Texas to southern Canada, an area much larger than most countries. At 172.6 centimeters on average, the men were taller than any national population for which evidence is available for the mid nineteenth-century (Steckel and Prince 2001; Prince and Steckel 2003). Komlos argued against the conclusion, reporting that some groups within the United States, such as rural residents of Georgia born in the 1820s exceeded the average height of the Plains tribes (Komlos 2003a). While true, Steckel and Prince qualified their comparison to the average height of countries whose individuals were born near the middle of the nineteenth century, when most of the people in the Boas sample were born. The chronological qualification is important because Euro-American heights declined for cohorts born after 1830. Plausibly the Plains tribes were also taller prior to 1830 , before epidemics and incursion by whites imposed physiological stress. In addition, if subgroups are the appropriate standard for comparison, at 176.7 centimeters the northern Cheyenne were also taller than any subgroup listed by Komlos.

In any event, perhaps the most interesting feature of the Plains data is the wide range of average heights across tribes. Amounting to nearly 9 centimeters, this range exceeds by nearly 3 centimeters the growth in average height of Euro-Americans from the early 1700 s to the present. Because the tribes had similar technologies and life ways, presumably ecological conditions and the differential pace of incursion by whites were relevant for their health. Steckel is now investigating these questions.

Pre-industrial England. In the 1990s the Economic History Review published a vigorous exchange between Komlos and Grubb on the course of heights in eighteenth century England. The major issue is whether the country suffered a pre-industrial Malthusian crisis in the early part of the century, as claimed by Komlos. Grubb published his last paper on the debate in 1995, and after controlling for geographic 
variation, using different procedures to assign non-metric heights and ambiguous ages, reports that no systematic trend existed (Grubb 1999b). Moreover, using additional height data on ads for runaway servants placed in the Pennsylvania Gazette, he finds that heights of men (but not women) increased over the eighteenth century (Grubb 1999a).

Was there a pre-industrial decline in stature? The sample size for any such claim is modest, but Grubb has added new evidence and followed plausible analytical procedures. Until additional evidence is brought forward in the debate, it is reasonable to doubt that physical growth in the mid eighteenth century suffered from a Malthusian encounter. This is an important question on which other scholars are working.

Russia. Papers by Mironov, Hock, Wheatcoft and Komlos debate biological aspects of living standards in Russia from the late 1800 s to the mid-twentieth century, a country and an era with questionable statistics on traditional measures of social performance. Mironov opens the discussion by claiming that heights measure important aspects of health, and using military records, concludes that Russians lagged behind western Europeans but were taller than people from eastern and southern Europe prior to World War I (Mironov 1999a). Wheatcroft extends the analysis to the middle of the twentieth century, noting crises years of 1899-1909, 1913-1918, and 1923-1934 amidst substantial long-term improvement in human welfare as measured by average height and by mortality rates (Wheatcroft 1999). Brainerd reports that stature and mortality rates fluctuated dramatically during the crisis years but showed no overall downward trend until the late 1960s (Brainerd 2006). Hoch emphasizes limitations of the Russian height evidence, including shortfall created by minimum height standards in the military, notes that Mironov and Wheatcroft disagree on the timing and extent of fluctuations, and chastises them for attempting to date episodes physiological stress using adult heights, which are influenced by socioeconomic conditions over many years of physical growth (Hoch 1999). Komlos enters the fray by observing that the Soviet improvement in health, emphasized by Wheatcroft, was hardly exemplary, with numerous countries such as Mexico, the Philippines, Spain, Chile and Jamaica achieving more for their citizens, and that the Soviet record was especially poor after 1960 (Komlos 1999). In a 
review of all these papers, Mironov focuses on Hoch and especially his skepticism toward heights as a useful measure of human welfare, while defending the anthropometric evidence as superior to other sources available (Mironov 1999b). All participants agree, however, that lack of traditional evidence makes Russia well-suited to anthropometric research and that gathering and analysis of evidence has only just begun. In this vein Mironov and A'Hearn recently extended the chronological span of research on Russian heights back to the middle of the eighteenth century (Mironov and A'Hearn 2008).

Slavery. The extraordinary height-by-age profile of American slaves is one of the most arresting findings of the new anthropometric history. The young slave children were among the smallest ever measured yet through compensatory or catch-up growth of nearly 5 inches that began in adolescence, adults exceed the heights of Stuttgart aristocrats and the upper classes of Italy and fell less than one inch below Union troops who fought in the Civil War and cadets at England's Sandhurst military academy (Steckel 1986; Komlos 2007b). As one of the most heavily cited articles in the Journal of Economic History, two lines of debate have emerged over these findings: selectivity in the height-by-age profile induced by traders or by mortality, and explanations for the growth recovery of teenagers.

In 1992 Pritchett and Freudenberger pondered potential biases imposed on slave manifests by traders who selectively purchased "lemons" (short slaves) or, alternatively, who saw transportation cost advantages in exporting higher quality (taller) individuals (Pritchett and Freudenberger 1992). They compared heights reported on "certificates of good character" required by Louisiana law in 1829 with those on inward manifests to New Orleans, reporting that the extent of catch-up growth was probably understated by the manifests. Komlos and Alecke counter the theoretical and empirical basis of their conclusions, claiming no upward bias existed but that the average heights of children on the manifests were shorter than free black children in a Maryland sample (Komlos and Alecke 1996). In subsequent work comparing the heights of children shipped by traders and non-traders, Pritchett reports that his estimates of upward bias diminished 
substantially with age, reinforcing the claim that the manifests understate catch-up growth (Pritchett 1997).

Skeptics of height studies have noted correctly that selective mortality tends to eliminate short people from the height distribution. Does this weaken the claim that average height is a good measure of health? Does selective mortality create a negative correlation between average height and life expectancy, i.e. short populations are healthier than tall ones (Riley 1994). If so, the growth recovery observed among teenage slaves might have been exaggerated if not created by the selective death of the short. Bystanders to this discussion should know that population-wide physiological stress also reduces the height of survivors and that the very tall are also more likely to die than individuals of typical height. Contrary to the selectivity hypothesis, average height and life expectancy are highly correlated at the national level (Steckel 1995b). With regard to slave catch-up, Steckel recently completed simulations showing that under a wide range of model life tables, selective mortality explains less than 5 per cent of the height gain after age 10.

The 1986 paper argued that stunting from a poor diet was profitable, partly because humans are resilient and have a considerable capacity for catch-up growth if conditions improve before adolescence. A plausible model of planter decision-making supports the profitability argument (Rees, Komlos et al. 2003). An alternative explanation hinges on reduced exposure to pathogens, specifically hookworm. Coelho and McGuire argue that young children were heavily exposed to this parasite around the plantation nurseries but working teenagers largely escaped because they wore shoes and/or the infective larva were far less prevalent where they worked in the fields (Coelho and McGuire 2000). Steckel notes that reduced hookworm exposure could be relevant but intervention studies in developing countries report small growth recovery (about 0.3 centimeters) by infected children who underwent medical treatment, which is a tiny per cent of the observed catch up growth (Steckel 2000). Steckel has coded and is now analyzing the entire collection of slave manifests available at the National Archives on nearly 150,000 individuals to prepare a book-length manuscript that will revisit this and many other topics in the health and nutrition of American slaves. 
Smallpox. All historical demographers know that smallpox periodically ravaged human populations well into the twentieth century, causing socioeconomic chaos. Although the disease is long-gone, historical study of smallpox generates sharp disagreement. Using data collected by the Marine Society, Voth and Leunig argue that because individuals who survived were approximately one inch shorter than those who never had the disease, the sharp reduction in smallpox in their sample beginning in the 1820s substantially improved heights (Voth and Leunig 1996). Razzell agrees that smallpox reduced height but argues that the disease was prevalent in London well beyond the 1820s and that the Marine Society recruiting officers probably missed some smallpox cases (Razzell 1998). Heintel and Baten take issue with the Voth-Leunig statistical methods, rejecting the claim that smallpox reduced height, and observe that changes in minimum height standards invalidate their chronological comparisons in any event (Heintel and Baten 1998). Studying literacy and the recording of smallpox, Leunig and Voth reply that Razzell's concerns are trivial as a practical matter (Leunig and Voth 1998). They also counter the Hentel-Baten statistical methods as unnecessary, unsuitable and unreliable when based on very small sample sizes. In a continuation of the debate, Razzell objects to the Voth-Leunig use of literacy as an index of accuracy in recording smallpox (Razzell 2001), but Leunig and Voth reply that Razzell misread the original data and moreover, when restricting the analysis to boys who were recorded as literate they find the negative effect of smallpox was three times larger than found in the pooled sample (Leunig and Voth 2001).

Pursuing the discussion with new data on height and smallpox from prisoner records, Oxley reports that smallpox sufferers were stunted in London but not other parts of the UK, suggesting that growth failure from the disease was connected to urban disamenities (Oxley 2003). Leunig and Voth reply that coefficients on smallpox are negative at all locations, as Oxley observes, but when her small subsamples are combined in a more sophisticated way through meta-analysis, then the negative effects systematically existed at all locations, not just London (Leunig and Voth 2006). In subsequent work Oxley adds another 34,000 prisoners to her database and also refines 
the definition of urban and rural, reporting that the smallpox effect varied by not only by location but age, gender, and time period (Oxley 2006). She concludes that the consequences of smallpox on physical growth were mediated through time and place.

Work and the Habsburg Empire. It is well-known that work or physical effort may create a significant drain on net nutrition, yet comparatively little research has gone forward on this important topic, I suspect because reliable measures of effort are difficult to obtain. Nevertheless we do have some modern estimates of caloric expenditure for various types of activities, which would advance understanding or at least place bounds on answers to interesting historical questions. In fact one of the important contributions of anthropometric history has been to explain why diets must be evaluated in relation to work and disease.

In various publications John Komlos argues that a Malthusian crisis reduced stature and stimulated technological change in the late eighteenth-century Habsburg Empire. Voth challenges this view by estimating regression models showing the height decline resulted from additional work associated with a reduction in the number of religious holidays, first in the 1750 s and then again in the early 1770s (Voth 1995). Komlos and Ritschl respond on several fronts, indicating that hours of work under the new policy would have increased work effort by a modest amount, more work likely led to better diets or at least higher incomes, and that the height decline occurred in countries where there was no change in the number of holidays (Komlos and Ritschl 1995). They substantiate their point by estimating Voth's equations using the entire data set. Voth maintains that high correlation between work days and the time trend invalidates their tests of significance and that work days alone perform better than the time trend (Voth 1996).

Multicollinearity is best addressed with additional data, and one wonders whether there was geographic variation in the introduction of work days that could be econometrically exploited. While the Komlos-Ritschl regressions have their problems, Voth does not confront the larger point that heights also fell in other countries. Some careful econometric work on the timing and possible causes of the late eighteenth 
century height declines across European countries would be a welcome addition to the literature.

\section{Convergence}

In recent years numerous papers have appeared in the macro, trade and regional economics literature on geographic convergence in social performance across countries or regions, often assessed by per capita GDP or by real wages. Central questions are the speed of convergence and factors that influence it, such as openness, transportation costs, labor mobility, and institutional structure. The first paper appearing in the height literature on this subject considered stagnation in the northwest region of Argentina during the first half of the twentieth century, where skills, education and social standing retarded physical growth relative to other parts of the country (Salvatore 2004b). Arcaleni next applied the methodology to Italy, where she found the South began to catch-up to the North in height and in other social indicators over the twentieth century (Arcaleni 2006). In studying the Habsburg monarchy Komlos found a 3.3 centimeter difference in average height between the core and the periphery in the midnineteenth century, with gradual convergence beginning near the end of the century (Komlos 2007a). Meisel and Vega study heights in Columbia reported on some 9 million national identification cards and passport records over the twentieth century, reporting considerable geographic as well as social convergence in stature (Meisel and Vega 2007). Considering the U.S. from 1820 to 1900 Chanda, Craig and Treme describe divergence across states during the period of declining average stature in the middle of the century, followed by classic convergence near the end of the 1800 s when average heights for the country recovered (Chanda, Craig et al. 2008). New results for Italy reveal that a regime switch took place in the late 1800s, in which heights converged from 1855 to 1880 but diverged from 1880 to 1910 , a finding that challenges traditional interpretations of regional social performance (A'Hearn, Peracchi et al. 2009 forthcoming). Given the large volume of height data now available, one can imagine that these interesting papers have just scratched the surface of the convergence research agenda relative to what will be available in the coming decade. 


\section{Crises in social performance}

The physical growth of children quickly declines or ceases with the arrival of adverse socioeconomic conditions, and if bad times persist, stunting registers in adult heights. The growth of children is therefore best for pinpointing the time and duration of short-term adversity but adult heights decline or fall below trend if adverse conditions are particularly severe, continue for a substantial period of time and/or occur during sensitive periods of growth, which are early childhood and adolescence.

The expansion of research on crises marks one of the most interesting policyrelated developments in the anthropometric literature. In contrast with heights, traditional measures such as unemployment rates and GDP do not monitor or reflect resource allocation within the household. By traditional measures, children are largely invisible. The extent to which children are nutritionally vulnerable in times of crisis is an important mark of a society's priorities and its willingness to invest in the future.

Because children's heights are scarce prior to the twentieth century, and the numbers are modest until the middle of the century, most historical studies use adult heights. That said, Komlos and collaborators have been writing for several years about a Malthusian crisis that occurred in Europe near the end of the eighteen century (Komlos and Heintel 1999; Komlos, Hau et al. 2003; Cinnirella 2008a). Interesting papers have also been written on the consequences for young adult stature of phylloxera (an insect that attacks the roots of grape vines) in late nineteenth-century France (Banerjee, Duflo et al. 2007); of social and economic turmoil in Mexico and the American Southwest (Carson 2005); agrarian reforms and crises in Poland (Kopczynski 2007); the burden of taxes in late eighteenth century Russia (Mironov and A'Hearn 2008); political and economic upheaval during the first 35 years of Soviet power (Wheatcroft 2009) and in Russia in the 1990s (Mironov 2007; Stillman and Thomas 2008); and the shocks of World War I and the Great Depression on heights in Argentina (Salvatore 2004a).

Two strands of literature have emerged on the health of children during crises, the most numerous focusing on developing countries, where considerable height data 
have been collected since the mid 1980s. In this vein papers have appeared on Cameroon (Pongou, Salomon et al. 2006); Kazakhstan (Dangour, Farmer et al. 2003); North Korea (Schwekendiek 2008b); Novi Sad (Bozić-Krstić, Pavlica et al. 2004); South Africa (Hendriks 2005); and Zimbabwe (Alderman, Hoddinott et al. 2006; Hoddinott 2006). The growth of adolescent boys fluctuated seasonally with the supply of food in Czechoslovakia (Cvrcek 2006).

One might expect that seismic shifts or differences in political systems adversely affect the health and welfare of children. The stature of children in Nazi Germany stagnated from 1933 to 1938 following autarchy and market disintegration (Baten and Wagner 2003). North Koreans declined in health relative to the South in the late twentieth century (Pak 2004), and were poorly equipped to deal with a famine that appeared in the 1990s (Schwekendiek 2008b). Delivery of United Nations food aid, however, seems to have improved anthropometric outcomes (Schwekendiek 2008a). Eastern Europe and Russia during the transition in the 1990s were different, whereby life expectancy deteriorated, especially in Russia, but anthropometric data suggest children were protected (Stillman 2006). Apparently adults bore the brunt of declining socioeconomic conditions during and immediately after these regime changes.

\section{Determinants of height}

To help understand this section it is useful to think of the body as a biological machine, which consumes food as fuel--a blend of calories, protein, micronutrients and other ingredients. This machine expends fuel at rest (basal metabolism) amounting to some 1,200 to 1,400 calories per day (depending upon size of the person) to breathe, keep warm, circulate the blood and so forth, and in physical effort, fighting infection and physical growth. In the most arduous activities, such as mushing (guiding a dog sled) in Alaska's 1,100 mile Iditarod dog race, energy expended may amount to 10,000 calories per day. For this reason diets are adequate or inadequate only in relation to demands on the fuel. Infections may consume fuel by raising body temperature and/or mobilizing the immune system, or through incomplete processing of the diet, especially in gastrointestinal diseases. The body's first priority is to survive, and growth stagnates or 
takes a back seat under conditions of inadequate net nutrition (diet minus claims on the diet made by work and disease). If good times return, the body may recover much or all of foregone growth through a process of catch-up, whereby velocity exceeds that typical for a given age. Malnutrition that is acute but severe retards growth and may lead to permanent stunting, depending upon its duration, severity and quality of conditions thereafter. Chronically poor net nutrition inevitably stunts adult height by as much as 10 to 15 centimeters, and possibly more in extreme situations.

Physicians, medical anthropologists and human biologists typically seek explanations for human growth in terms of processes that operate at or below the cellular level. Examples are the quantity and quality of protein and the role of micronutrients such as iron or iodine in the diet, which might be called proximate biological determinants. Social scientists mobilize their explanatory forces at a much higher level of aggregation--the individual, regions, ethnic groups, countries and so forth-and typically harness familiar socioeconomic variables such as income, migrant status, availability of health insurance, inequality, or occupation. Ultimately these socioeconomic variables operate through proximate biological forces on human cells that create physical growth, and thus some knowledge of the medical literature is essential to conduct good anthropometric history. Most medical scientists, however, have little knowledge or perhaps little interest in socioeconomic processes, and therefore have conducted little research illuminating the connection between socioeconomic conditions and human growth.

This task has fallen to social scientists, who face the hurdle of learning some biomedical literature, to understand the complexities of the growth process in relation to limitations of the data available to understand it. The latter arises because the most common historical evidence, and indeed much modern data, consists of adult heights. Human growth, however, unfolds over some 20 years, from conception to maturity; there are sensitive periods such as early childhood and adolescence; a multitude of socioeconomic variables potentially operate at each age; and genetic conditions may interact with environmental ones. Adult heights merely summarize the final result, and if this is all that's available (as opposed to longitudinal height on height and 
socioeconomic conditions at each age), then researchers face a huge identification problem in which there are far more determinants than outcomes.

Therefore the greatest achievement of the new anthropometric history to date has been to establish height as a useful measure of human welfare, which can be compared to or with other familiar examples such as income, wages, inequality, or life expectancy. Of course, to properly interpret the meaning of average height as social scientists, we should know which socioeconomic forces affect it and how powerful they are (or were). The research needs in the area are huge and I expect it will take many years to complete the agenda, if that is ever possible given the data limitations. What has been published since 1995 merely continues an important down payment that extends efforts made between the late 1970s and 1994. Height researchers should not be discouraged, however: after more than half a century macroeconomists are still constructing models to explain the determinants of a somewhat different but related welfare measure, GDP. Realistically, however, all that we may be able to achieve as social scientists is a good intuitive understanding of socioeconomic influences on physical growth, informed by imperfect quantitative studies.

Since 1995 five general publications have appeared on determinants of stature, including a monograph by Barry Bogin and four edited collections of papers assembled by John Komlos and collaborators (Komlos 1995a; Komlos 1995d; Komlos and Baten 1998; Komlos and Cuff 1998; Bogin 2001). Readers will find these books to be compact and useful sources of information on anthropometric research and methods.

As a group the research emphasizes economic conditions, including business cycles (Woitek 2003; Sunder and Woitek 2005); income (Dick 1995; Drukker and Van Meerten 1995; Jacobs and Tassenaar 2004); income combined with disease (Coclanis and Komlos 1995; A'Hearn 2003); income combined with nutrition (Strauss 1995; Svedberg 2000); inequality (Cavelaars, Kunst et al. 2000; Alter and Oris 2008); taxation (Mironov and A'Hearn 2008); socioeconomic status (Voss, Mulligan et al. 1998) (Webb, Kuh et al. 2008); food prices (Christiaensen and Alderman 2004; Meng, Gong et al. 2009); and access to roads in rural areas of poor countries (Gibson and Rozelle 2003). Research on the past of several countries, and most recently that on Italy (Peracchi 
2008), indicates that the height-income relationship is not stable in the face of changing epidemiological conditions. At a given level of income improvements in public health, personal health life styles and childcare practices, reduce the prevalence of disease and enhance physical growth.

Several studies report the importance of mother's education for child health and physical growth, with a recent case study for Russia (Fedorov and Sahn 2005). The mechanism operates in two ways on the health and height of the child, via cognitive ability (Rubalcava and Teruel 2004) and informed child-care practices (Shariff and Ahn 1995; Christiaensen and Alderman 2004). Consistent with this interpretation, a study on Vietnamese children found that the effect of parental education remains powerful when controlling for income, which suggests that the effect of education operates directly on height rather than via income alone (Haughton and Haughton 1997). In Jamaica, where females in the household often share child-care responsibilities, increased education of any woman had a positive impact on child health (Handa 1999). Children of the household head were nearly half a standard deviation taller than other children in the household, which suggests that the head was able to direct resources to their own children. One may wonder whether the head was also able to enhance the education of her own children. In these same households, presence of the father had a large positive impact on children's height, even when controlling for household income, a pattern that would be interesting to investigate for the past.

Although numerous studies document the importance of formal education of parents on child growth, one may ask whether nutritional knowledge gained informally from relatives, friends, the media, and community health services can enhance the benefits of formal learning (Webb and Block 2004). Analysis of survey data from rural Java confirms that formal schooling is important for standardized height for age scores (a measure of long-term nutritional status), and that short-term health outcomes, as measured by weight for height, were heavily influenced by maternal nutritional knowledge gained from a marketing campaign.

Several studies report height differences by geographic area, which summarize a multitude of forces such as income, public health investments, migration, exposure to 
disease and to sunlight (A'Hearn 2006; Tatarek 2006; Cranfield and Inwood 2007; Carson 2008a; Carson 2009). Haines and Kintner link greater height among early twentieth-century German soldiers to birth in geographic areas where breast feeding was relatively more common (Haines and Kitner 2008). A household-level study of infant growth in Brazil independently confirms breastfeeding's beneficial effects (Senauer and Kassouf 2000). Other things equal, children from dairying regions tend to be taller, but when combined with proximity to a large city in the nineteenth century (Philadelphia) the urban penalty trumps the benefits of access to dairy products (Carson 2008b). Studies report that migrants tend to be taller on average than the people they left behind and that for children, catch-up growth occurs in moving from poor to rich countries (Smith, Bogin et al. 2003; Danubio, Enrica et al. 2005; Böetsch, Brus et al. 2008; Carson 2008d; Humphries and Leunig 2009b).

Socioeconomic conditions that reduce mortality also increase average height, a result found by linking data on conscript heights with post-neonatal mortality rates (Schmidt, Jørgensen et al. 1995). A similar relationship with childhood mortality rates was found for groups of counties within the United States in the early twentieth century (Haines and Steckel 2000). In a worldwide sample of life tables from 1940 to 1970 , average height was highly correlated with mortality rates, exceeding 0.85 in some cases (Gage and Zansky 1995). A theory of technophysio evolution, by which improved nutrition in utero and early childhood enhances vital organ systems, has been proposed as a biological mechanism underlying the height-mortality relationship (Fogel and Costa 1997). A related theory argues that infections and inflammation that retard early growth also contributes to cardiovascular diseases of old age (Crimmins and Finch 2006).

Angus Deaton has identified a puzzle in the relationship between average height and traditional measures of social performance for Africa relative to the rest of the world (Deaton 2007). Africans, especially women, are too tall relative to what would be predicted (based on patterns observed in other continents) by their low incomes and high childhood mortality. Genetic selection over the eons for conditions specific to Africa might explain the pattern but he emphasizes alternatives. One hypothesis is that high childhood mortality, selected heavily on height, erodes the lower tail of the height 
distribution. This hypothesis could be investigated through simulation using various life tables and survival rates in relation to physical growth, and by examining the frequency distribution of stature in relation to mortality rates for various African countries. It is also possible that measured socioeconomic data for Africa do not accurately reflect experience, in which foraging and home production could play a major role in diets, or in which barter and the underground economy are not captured by national income accounts.

In investigating socioeconomic influences on physical growth, it is important to distinguish household from community influences, and possible interactions between the two. An interesting study on the Philippines assembles data for both entities (Ghuman, Behrman et al. 2005). The researchers report that several household variables improved growth as expected, including parent's height and schooling, but they found no systematic interactive effects on child height between household variables and community characteristics, such as number of nurses, doctors and sanitation inspectors (although interactions existed for hemoglobin levels and occurrence of worms). In my view, the case is far from closed on interactions and their implications for omitted variable bias in assessing influences on stature, and researchers should continue to be vigilant in attempting to control for community level variables where possible.

Diet and nutrition affect human growth, and the connections found by social scientists illuminate the role of mechanical refrigeration (Craig, Goodwin et al. 2004); relative price changes (Logan 2006); social policy (Pelletier and Frongillo 2003); general living conditions (Silventoinen 2003); diet and work (Tadman 2000); socioeconomic conditions associated with ethnicity (Brennan, McDonald et al. 1995; Dye 1995); parental consumption decisions (Schneider 1996); the interaction of diet and disease (Alter 2004); political disruption (Costa-Font and Gil 2008; Morgan 2009); and railroads (Solakoglu 2007). Although democratic socialist countries devote considerable resources to human welfare programs, a modest height gradient often persists (Turrell 2002). 
The pre-famine Irish were relatively poor but tall by European standards prior to the potato famine because they existed largely on a nutritious (but boring) diet of potatoes and milk (Nicholas and Steckel 1997). One might suppose that children who worked at sea in the mid-nineteenth century would have been stunted by the experience, but Humphries and Leunig find the reverse, arguing that wages were largely paid to the child in the form of food and shelter (Humphries and Leunig 2009a).

Relationships discovered between socioeconomic with anthropometric measures have stimulated efforts to improve social policy in developing and middle-income countries (Popkin and $\mathrm{Ng}$ 2007). Physical work, especially that requiring substantial effort, reduces net nutrition and can retard the growth of children if diet and/or medical care are inadequate, which is often the situation in developing countries (Ambadekar, Wahab et al. 1999; Hawamdeh and Spencer 2003; Cortez, Barbieri et al. 2007).

Some researchers reverse the direction of causation, considering ways that heights influence socioeconomic decisions rather than pathways by which these conditions determine heights. In this vein, Baten and Murray, and Hacker investigate how stature affects marriage prospects (Baten and Murray 1998; Hacker 2008) and Humphries and Leunig consider the impact of stature on the decision to migrate (Humphries and Leunig 2009b).

In an interesting study on household data from Ethiopia, Ayalew investigates whether parents invest differentially in the human capital of their offspring, based on child endowments in health (measured by stature) and by their scores on standard tests (Ayalew 2005). The results suggest that parents try to compensate for health inequities but actually reinforce differences in educational endowments, devoting more resources to the education of children with greater ability. If the latter investment pattern existed in the past, parents may have increased inequality over time in society as education grew in important to the production process.

\section{Development}

Heights are an excellent measure of biological deprivation, and the extremes of socioeconomic conditions often found in developing countries creates large absolute 
differences in stature, which makes this setting particularly valuable for studying the causes and implications of physical growth. Anthropometric studies in these countries have flourished over the past two decades because substantially more evidence has become available on height and weight, which are linked with various socioeconomic variables in household surveys. Among these the Living Standards Measurement Surveys (LSMS) administered by the World Bank, and the WHO Global Database on Child Growth and Malnutrition are exceptionally important (Grosh and Glewwe 1995; de Onis and Blössner 2003), and the findings from these and similar data sources have been published in numerous outlets. As might be expected, many publications consider the effectiveness of policy interventions and economic change on child health. In this regard, much work has been done on Africa (Lavy and et al. 1996; Thomas, Lavy et al. 1996; Alderman, Hoogeveen et al. 2006; Yamauchi 2008; Alderman, Hoogeveen et al. 2009) and on South America (Alves and Belluzzo 2004; Attanasio, Gomez et al. 2004; Behrman and Skoufias 2004; David, Narci et al. 2004; Gertler 2004), as well as some on Asia (Morgan 2004; Chaudhuri 2008). Recent work has suggested ways to combine various anthropometric indicators collected in these surveys into a composite index (Bhattacharyya 2006) or otherwise gauge nutritional vulnerability (Chilima 2000).

The range of socioeconomic conditions found in developing and middle-income countries are conducive for studying determinants of height. Various papers consider the impact of child labor (Galiani and Schargrodsky 2004; Roggero, Mangiaterra et al. 2007); maternal education (Handa 1999; Dasgupta, Saha et al. 2008); income or poverty (Morgan 2000; Gaiha and Kulkarni 2005); schooling and wealth (Chilima 2000; Godoy, Reyes-Garcia et al. 2005); influences associated with geography and culture (Morales, Aguilar et al. 2003; De Souza 2006); political oppression (Louw and Henneberg 1997; Cameron 2003); and economic and health conditions in early childhood and adolescence (Akachi and Canning 2007). Public health investments in Peru during the 1990s had a small but disproportionate beneficial effect on the urban poor but failed to reach poor children in rural areas (Valdivia 2004).

To gauge from citations to each other's literature, anthropometric history and anthropometrics in development economics have relatively little interaction. This is a 
pity because each group has much to gain by creating a two-way street. The rich household data sets now available for developing countries provide numerous insights into socioeconomic determinants of stature that can inform historical studies. At the same time, the wide range of economic, institutional and political conditions found in historical settings exceed those found in the developing world, and this diversity provides useful perspective on the causes, consequences and prospects for alleviating poverty and deprivation in the modern world. Only a few generations ago the average adult male in several now-rich countries of Europe and Asia was 158 to 164 centimeters (Komlos 1995a; Komlos 1995d; Steckel and Floud 1997), which is smaller than the typical poor adult male in many of today's developing countries (Eveleth and Tanner 1976, 1990).

\section{Fetal origins hypothesis}

Careful sifting of epidemiological evidence assembled for the UK in the 1980s led David Barker and colleagues to hypothesize that several adult diseases, such as hypertension, type II diabetes and some cancers, could be traced to health conditions in a critical formative period of early life, from conception through early childhood (Barker 1994). Although medical experts disagree on the biological mechanism by which health in early life extends into adulthood, the empirical regularity is well established and is sometimes called the fetal origins hypothesis or the Barker hypothesis (Blackwell, Hayward et al. 2001). Because early childhood conditions are important for adult height, several studies use stature as a marker to predict longevity and/or adult disease patterns (Riley 1994; Harris 1997; Murray 1997; Jousilahti, Tuomilehto et al. 2000; Costa 2004; Christensen, Djurhuus et al. 2007). Of course, other measures of early childhood health have been used in this line of research, including body mass index (Henriksson, Lindblad et al. 2001; Linares and Su 2005), child mortality rates (Bozzoli, Deaton et al. 2007), exposure to epidemic disease (Almond and Mazumder 2005; Almond 2006), and skeletal markers of physiological stress (Steckel 2005c). Recently economists and other social scientists have investigated ways that early childhood health affects cognition and skill formation, which sheds light on the optimal design of 
public policy (Heckman 2006). Such policies should note the intergenerational consequences of a mother's reproductive fitness because healthier female children later have healthier babies (Osmani and Sen 2003).

Some economic historians are already putting the health-cognition ideas to good use by linking proxies for physiological stress in early childhood with numeracy, or the ability to recall one's precise age, in this case for census enumerators in nineteenth century Britain (Baten, Crayen et al. 2008). Although the evidence is circumstantial, it is plausible to believe that grain prices and welfare subsidies under the Poor Law impacted early childhood net nutrition and cognitive development, and thus numeracy rates found among these children as adults. This type of study opens an entirely new dimension to height research for understanding the nutritional underpinnings of human capital acquisition, technological change, innovation and economic growth.

\section{Gender}

Until recently men dominated or controlled labor market activity, political decision making and property. In constructing and analyzing traditional measures of social performance such as GDP, earnings and wealth, which are (or were) largely produced or owned by men, many economists tacitly assume that material goods and services are (or were) equitably distributed within the household. But is (or was) this the case? It is desirable to have direct information on the fates of children relative to adults and girls relative to boys. How did these groups fare during industrialization? Is (or was) there gender discrimination in some societies? Numerous methodologies have been used to address the issue (Lundberg 2005), and heights can provide some answers. To make proper comparisons, the heights of men and women must be standardized for biological differences in growth potential, with results translated into z scores or percentiles of modern height standards.

In the developing world considerable research has gone forward using the LSMS and similar surveys (Strauss and Thomas 1995). Contrary to predictions of the unitary model of intra-household resource allocation, which maintains that both parents have the same preferences for the wellbeing of sons and daughters, some studies find 
preferences in allocation of resources to boys or to girls that correspond to the resources or human capital available to the parent of the same sex. For example, pensions received by women in South Africa had a greater positive impact on the physical growth of girls than boys (Duflo 2003). A study by Sahn and Stifel using the Demographic Health Surveys reports this result holds more generally in Africa (Sahn and Stifel 2002). Similarly, mother's education had a greater positive impact on the height of daughters within an indigenous population of Brazil (Godoy, Reyes-Garcia et al. 2005; Godoy, Leonard et al. 2006).

If mothers and fathers have preferences for children of their sex, one may suspect that the sex composition of the household affects the allocation of dietary resources. A study in rural India suggests that both boys and girls had poorer outcomes (height) if they were born after multiple same-sex siblings; boys born after multiple daughters, however, had the best outcomes (Pande 2003). In the 1990s economic growth improved living standards in India, and height gains occurred for both sexes of young children in the cities but girls lagged behind boys in rural areas, especially in the northern part of the country where research documents a preference for sons (Tarozzi and Mahajan 2007). Deaton reports that an excess of Indian males (consistent with relatively higher female mortality) was positively correlated with the percentage difference in their heights relative to the average height of males and females (Deaton 2008). In the Dominican Republic boys and girls fared similarly in female versus male headed households but if the household was poor, children fared somewhat better with a female head (Rogers 1996). According to evidence gathered upon admission to the London House of Correction in the Victorian era, anthropometric indicators disproportionately declined for women if the family became larger and/or their economic resources declined (Horrell, Meredith et al. 2009). Some believe that strong son preferences exist in Vietnam but a study on data from the early 1990s found no differences in standardized height or weight for age achieved by preteen boys and girls (Haughton and Haughton 1997).

Much of the debate over the distributional consequences of industrialization has focused on differences by class or region, but recent studies now shed light on gender. 
The general expansion of anthropometric history has led researchers to develop new sources of data such as prison records, which are skewed towards males but otherwise represent reasonably well the teenagers and younger adults of the working class. Although women are a distinct minority in prison admissions, in absolute numbers the female heights are abundant in many states and countries.

England has garnered the largest share of research on the relative health of women during industrialization. Johnson and Nicolas show that heights of men and women reported by London's Scotland Yard declined from the late 1820s through the 1850s, with the hungry forties being the worst period to have been born (Johnson and Nicholas 1995). Note, however, that the negative coefficients on their time period dummies are generally larger for women than men, a result that understates the stress on women because they were shorter (hence their percentage decline in height was larger) and for biological reasons, women are ordinarily more resilient than men. In subsequent work on heights of convicts sent to New South Wales from England and Ireland covering birth years from 1785 to 1815 , Nicolas and Oxley report that women's heights fell relative to men's and that women living in rural as opposed to urban areas underwent more physiological stress (Nicholas and Oxley 1996), but Jackson disputes their result of a downward trend on grounds of statistical procedure (Jackson 1996). In a final effort to settle the question, Johnson and Nicholas analyze 30,000 heights on female prisoners from three sources, which they compare with male heights assembled by other researchers (Johnson and Nicholas 1997). They reiterate the presence of a growing height gap between men and women up to the end of the Napoleonic Wars but thereafter their heights moved in parallel, which suggests that factors endogenous to the household economy led to deterioration for women during the early phase of industrialization. Moreover, heights in England declined relative to those in Ireland, which suggests that disamenities of industrialization imposed health penalties. Unlike the rest of pre-famine Ireland where heights declined, Ulster's nascent industrial economy competed favorably with that of England after the Napoleonic Wars, which translated into improving heights for women (Oxley 2004). 
Both men and women in nineteenth-century Bavaria benefited from a diet rich in milk and potatoes. Heights declined for women relative to men, however, during the hungry 1840 s and in contrast to what is known about biological resiliency, women's heights were more sensitive to economic conditions in early childhood (Baten and Murray 2000). On the other hand, research on heights gathered from passports issued by the United States shows that female heights increased more rapidly than those for men after the Civil War of the 1860s (Sunder 2007).

\section{Health and economic growth}

Casual empiricism suggests that health and economic growth are highly correlated if not causally related. The correspondence is far from perfect but rich countries of the late twentieth century are healthy and vice versa. Social scientists debate the strength and direction of causation, however, and height has entered the discussion as a measure of health in the papers cited below. The correlation is weakest in a long-run view, say over the past two centuries because, Richard Easterlin argues, the forces of market capitalism that gave rise to economic growth did not solve the externalities, agency problems and other market failures that had to be overcome by new government institutions, such as boards of health, to reduce exposure to infectious diseases and provide for immunizations (Easterlin 1999). These investments, which began in the mid-to-late nineteenth century and continue through the present in developing countries, consume a tiny portion of GDP and yield enormous rates of return.

Economists usually agree that better health improves economic growth, but they disagree on the impact and pathways. While the strength or contribution of each is unknown, it is easy to imagine possible mechanisms, such as diminished cognitive capacity, which reduces the effectiveness and the amount of schooling. Also connecting health to productivity are physical strength, stamina and days lost from work. In addition, greater longevity encourages workers to save for retirement, which promotes capital accumulation. Measuring these effects is more contentious and depends upon statistical methods and data sources. The World Health Organization 
recently formulated a macro perspective, which states that the "linkages of health to poverty reduction and to long-term economic growth are powerful, much stronger than is generally understood" (WHO 2001). Robert Fogel estimates that nutritional improvements reflected in height gains account for about 30 per cent of British economic growth over the past two centuries, principally by giving the ultra poor enough calories to enter the labor force and by giving more energy for work to those already employed (Fogel 2004b). David Weil investigates the micro foundations of the relationship using cross-country, historical data on heights, survival rates and age at menarche to conclude that eliminating health differences across countries would reduce the inequality between the $90^{\text {th }}$ to the 10 percentile of GDP per worker by approximately 20 per cent (Weil 2007). Arora used a century or more of height data for ten countries, reporting that health improvements increased their pace of economic growth by 30 to 40 per cent (Arora 2001). López-Casasnovas and collaborators undertake the most wideranging discussion in the literature, exploring various mechanisms by which health influences economic growth (López-Casasnovas, Rivera et al. 2005).

It is important to know the contribution of health to economic growth to properly estimate the pay-off to health infrastructure investments. Much work has been done, for example, on the economic value of life and the rate of return on clean water supplies as measured by mortality rates or life expectancy. Economic growth, however, is more complicated because a large number of variables affect it. Researchers therefore need to embed estimation procedures in complex models that accommodate numerous pathways and interactions as well as other influences on growth such as monetary policy, investments in schooling, technological change, and the like. Furthermore the payoff plausibly occurs over many years and the benefits may be intergenerational. Significant progress on the agenda requires agreement on the appropriate models for understanding economic growth, which is a major outstanding research question in economics. The problem is formidable but historical data may be important if not essential to move forward simply because the benefits of improving health unfold over a long period of time. 


\section{Industrialization}

Often arrayed into camps of optimists and pessimists, contributors have fashioned a lively discussion over the welfare consequences of industrialization (Steckel and Floud 1997). While most vigorous for England, the debate now encompasses many countries that industrialized in the eighteenth or nineteenth century. In the past 14 years 44 papers analyzing heights have appeared on the subject, with the largest number (10) on the United States followed by England (9), Germany (6), three each for Australia, Spain and Portugal, and two each for Japan, France, Italy, the Netherlands, and the Hapsburg monarchy. Scholars studying the first industrial country (England) established the framework for the debate: participants agree that industrialization eventually improved material living conditions for all groups, but controversy surrounds the extent of redistribution en route across socioeconomic groups and regions, the social and psychological adaptations required of men and women at work, and the disamenities of an urban-industrial way of life.

Evidence for the two most-studied countries shows persistent declines in stature of one to two inches during the heart of the process. Margo and Steckel, who discovered that heights declined after 1830 in the United States, initially questioned whether the cycle was genuine, as did Robert Gallman some 15 years later (Gallman 1996). Several independent sources of evidence have verified what is commonly called the "antebellum paradox" (Komlos 1996; Komlos and Coclanis 1997; Carson 2008b; Maloney and Carson 2008), or the decline in height and life expectancy in the midst of vigorous economic growth, and research now focuses on its possible causes.

Candidates include migration and the spread of disease; growing inequality; the appearance of business cycles that increased the nutritional vulnerability of the poor; rising food prices; the emergence of public schools that exposed young children to dangerous pathogens; the rise of commercial farming, which tempted farm families to trade farm surpluses for manufactured goods; the Civil War; and urbanization (Costa and Steckel 1997; Haines, Craig et al. 2003; Haines 2004; Sunder 2004; Cuff 2005; Carson 2008b). 
Several of these suspects may also apply to England, but the literature has emphasized urbanization, and various conditions associated with it, as a major culprit (Mokyr and O'Grada 1996; Crafts 1997; Floud and Harris 1997; Feinstein 1998; Komlos 1998; Szreter and Mooney 1998). Ewert links a decline in average heights in Saxony and Württemberg after the Napoleonic period to deteriorating climate and rising food prices (Ewert 2006), a result also reported by Cinnirella, who also cites higher food prices but gives weight to urbanization in the decline in Saxony (Cinnirella 2008a). Delajara blames the demographic transition in Europe for triggering a decline in children's heights that began in the mid-eighteenth century, which was followed by growth recovery that began a century later (Delajara 2004).

In a recent paper Cinnirella re-works the Floud-Wachter height data for England by focusing on the army recruits alone and using the truncated normal maximum likelihood estimator throughout the analysis (Cinnirella 2008b). He confirms the FloudWachter finding of height decline in the mid-nineteenth century but places the decent somewhat earlier, soon after the Napoleonic wars concluded. In his view, however, the recovery after the wars merely interrupted a long-term decline of roughly 7 centimeters from the middle of the eighteenth through the middle of the nineteenth century. Importantly, they differ on the outcome for the early industrial period, for which FloudWachter reported increases but Cinnirella found declines explained by Gregory Clark's evidence on rising food prices and declining real wages. Now that deteriorating conditions in the early-mid nineteenth century are clearer, it would be prudent to invest in additional data collection for the eighteenth century.

Countries that industrialized after the revolution in public health inspired by the germ theory of disease either had minor height cycles or experienced sustained upward trends, as was the case in Germany (Twarog 1997); the Habsburg monarchy (Komlos 2006); Poland (Kopczynski 2007); Portugal (Padez and Johnston 1999; Padez 2002; Padez 2003); Spain (Gomez-Mendoza and Perez-Moreda 1995; Carrión and Castejón 1998; Martinez-Carrion and Moreno-Lazaro 2007); Italy (Vecchi and Coppola 2006); Argentina (Salvatore 2009); Hungary (Gyenis and Joubert 2004); and Sweden (Sandberg and Steckel 1997). Australia is a borderline case, industrializing (or more 
properly, modernizing) during the public health movement and experiencing a modest swing in stature (Jackson and Thomas 1995; Whitwell, de Souza et al. 1997; Whitwell and Nicholas 2001). In eastern Belgium the men were relatively short during the nineteenth century but realized a sustained upward trend in average stature except for occasional setbacks associated with rapid urbanization (Alter, Neven et al. 2004). The Netherlands sustained a modest decline in average height in the early industrial period (Drukker and Tassenaar 1997). Increases in stature in Italy during the second half of the nineteenth century were led by improved diets and better sanitary conditions, the latter occurring before the germ theory was widely influential (Federico 2003).

Countries that industrialized in the mid-to-late nineteenth century had experiences straddling those the early and the late comers, but individual circumstances influenced the process. Moderate paces of urbanization and economic growth accompanied a trend of slow stature growth in France until the end of the nineteenth century (Weir 1997; Heyberger 2007). Despite rapid economic growth in the early twentieth century, Japan's height gain was retarded by diverting resources to the military (Mosk 1996; Honda 1997).

In sum, the adverse effect of urbanization on stature during industrialization was in rough inverse proportion to public-health applications of the germ theory of disease. Other factors such as population density, the pace of change, government priorities, and quality of the diet were also relevant. Based on the height data the pessimist case applies to the early industrializers but much less so to late comers that had the benefit of public health investments that flowed from the germ theory as well as improved transport that integrated markets for food. Thus the advantages of economic backwardness enunciated by Gerschenkron regarding the pace and prime movers of industrialization, also applies to the health costs because latecomers could emulate the new health technology.

\section{Inequality}

The discovery of an inverse relationship between economic inequality and a country's average height expanded the welfare implications of stature (Steckel 1983). 
So long as poverty exists (or existed) in a society, defined by lack of basic necessities important for human growth, redistribution from the rich, whose physical growth would not suffer (or suffer less) from loss of income, to the poor would increase the average physical growth of children. Thus inequality can be understood as a determinant of average height as well as a barometer of socioeconomic inequality if the data are arrayed by ethnicity, occupation, social class, region and so forth.

Since 1995 scholars have published 29 papers on inequality and height. Seven of them consider racial differences in biological aspects of the standard of living, with six on the United States (Bodenhorn 1999; Bodenhorn 2002; Carson 2008c; Carson 2008b; Maloney and Carson 2008; Carson 2009 forthcoming-a; Carson 2009 forthcoming-b) and one on Argentina (Frank 2006). Other topics studied with this approach are the fates of illegitimate children in Germany (Baten and Murray 1997) and implications of the socioeconomic status of the mother on the health of the child (Costa 1998). Komlos investigates the implications of height inequality for social and political change, in this case the French Revolution (Komlos, Hau et al. 2003). The greatest social-class difference in height on record amounted to 22 centimeters at age 16, which was found in England during the first half of the nineteenth century (Komlos 2007b). About the same time across the English Channel in Belgium the class difference in stature was 8 centimeters (Alter, Neven et al. 2004).

A second strand of the inequality-height literature considers the connection between inequality and economic growth, with a focus on developing countries such as India (Brennan and McDonald 2001; Mahal and Karan 2008); sub-Sahara Africa (Moradi and Baten 2005); China (Morgan 2004); Mexico (Lopez-Alonso 2007); and a cross-section of poor and rich countries (Deaton 2003). This body of literature also includes several papers on height inequality during industrialization in central Europe (Komlos 2006), Japan (Bassino 2006), England (Komlos 2007b), and Mexico (LopezAlonso and Condey 2003). In a new strand of research inequality has also been linked with changes in public policy, and in particular with protectionism in Latin America (Baltzer and Baten 2008). 
A third category of papers views inequality as a socioeconomic determinant of average height. As with many applications of stature, the range of topics is quite wide, including papers on India (Guntupalli and Baten 2006; Deaton 2008); Germany before and after reunification (Komlos and Kriwy 2002; Komlos and Kriwy 2003; Heineck 2006; Hiermeyer 2008); Norway (Sunder 2003); and a cross-section of modern Europe (Gylfason 2007). Interestingly, the unification of East and West Germany suggests there is a negative relationship between equality and average height.

Research on inequality using heights has a bright and important future because the topic cuts across the social sciences and into public policy. Moreover the outcome measure, the physical well-being of children, is not easily observed using traditional metrics. Finally, much can be learned about groups at risk by collecting relatively small samples that are very cost-effective in terms of knowledge gained. Because the care and feeding of children is under parental care in most societies, public policies must be receptive to families. The successful history of programs to improve personal hygiene in the early part of the twentieth century and, somewhat later to receive childhood immunizations indicates that such interventions can be effective.

\section{Living standards}

Fifteen papers published since 1995 integrate heights into a discussion of trends or differences in living standards. Several authors address the topic from a theoretical or philosophical as opposed to an empirical perspective. Coatsworth argues that study of human welfare, which can be assessed using heights as well as many alternative measures, is the central unifying purpose of history (Coatsworth 1996). Engerman invokes stature to help place the standard of living debate into international perspective (Engerman 1997). Komlos discusses heights in the context of the biological standard of living and Vecchi and Giovanni explore the deficiencies of traditional macro data using height as an alternative (Komlos 1995b; Vecchi and Coppola 2006). Chakravarty incorporates stature into a human poverty index, which concentrates on deprivation in the basic necessities of life (Chakravarty and Majumder 2005), and Wilk argues that stature is legitimately part of any effort to compare the quality of life (Wilk 1999). Tarp 
et al. report that $Z$ scores of height-for-age are highly correlated with other measures of poverty such as income relative to the cost of basic needs as the household level in Mozambique (Tarp, Simler et al. 2002). In two papers Steckel explains the contributions that height can make to understanding physical well-being and provides evidence for comparisons (Steckel 2006; Steckel 2008).

A second strand of this literature is more empirical, focusing on height statistics to help explain the historical record of human welfare. Easterlin's paper is the most comprehensive in its effort to depict progress on the human condition over the past two centuries (Easterlin 2000). A similar but less comprehensive assessment of human progress traces improvements in mortality, partly as proxied by heights, since the late eighteenth century (Cutler, Deaton et al. 2006). Svedberg demonstrates that anthropometric measurements are more reliable and relevant than estimates prepared by FAO using data on food availability, its distribution within countries, and suitable norms for assessing global patterns of malnutrition (Svedberg 1999; Svedberg 2002). Various scholars are now investigating why American heights have fallen behind those of several European countries (Komlos and Baur 2004; Komlos and Lauderdale 2007; Komlos 2008).

Now that stature is a widely accepted as a useful measure of living standards, and that height time series are available for numerous countries, anthropometric history is poised for investments in various comparative projects. Fifteen years ago when Roderick Floud and I organized the conference that led to Health and Welfare during Industrialization, the effort required most participants to assemble the raw data necessary to investigate the industrial period of eight countries: the U.S., Japan, Australia, England, the Netherlands, France, Germany, and Sweden. By now the number of countries for which data are available has expanded to the point that one could imagine separate comparative projects for Asia, for Eastern Europe and for Latin America. Moreover, enough evidence has been gathered or could readily be assembled for large comparative studies on the pre-industrial world and on physical well-being in the post-industrial period. It would be a great service to these efforts for some organization to create a repository for all height data that have been collected. 
Perhaps it is time to establish a center for height research that could be amalgamated with programs in economics, history, and anthropology as well as other social science disciplines and medicine.

\section{Long-term trends}

This section discusses eighteen papers that have a chronological prevue that is long by standards of economic history, exceeding two centuries. Among these one half are based on skeletal data, which can depict important aspects of health over much longer periods of time. Steckel set forth the methodology of research on skeletons in a paper given at the 2003 meetings of the American Economic Association (Steckel 2003b). Four papers focus on the Western Hemisphere, where a long term decline in health occurred prior to the arrival of Columbus (Neves and Costa 1998; Steckel and Rose 2002a; Steckel and Rose 2002b; Steckel 2005a).

With regard to the colonial period of the United States, the most surprising result is their remarkably tall stature, relative to any other populations for which height data are available (Sokoloff 1995; Steckel 1999; Komlos 2001). Forces usually cited as responsible for the exceptional net nutrition of colonial Americans are an abundance of good farm land relative to population size; near equality across socioeconomic groups; a combination of Old World and New World foods that provided dietary diversity; and low population density that limited the spread of communicable diseases.

In Europe the most intriguing result to appear from skeletal data is the remarkably tall stature of men during the early Middle Ages (Steckel 2004; Koepke and Baten 2005; Steckel 2005b; Koepke and Baten 2008). There was a long-term U shape to stature in northern Europe, with a minimum occurring near the seventeenth century. Not until the early twentieth century did Northern Europeans attain their stature of the early Middle Ages. Research on possible explanations for the first half of the $U$ is at an early stage but it seems likely that some forces differed from those behind the escape from hunger, or the gradual upward trend in stature that began in the 1700s. Fogel emphasizes improving diets driven by the revolution in agricultural technology, new crops, food imports from the colonies, and the eventual move toward free trade (Fogel 
2004a). Likely suspects for the decline are a cooling climate that followed the Medieval warm period; the rise of commodity markets within Europe that spread disease; urbanization; the world-wide exchange of disease that began with European exploration and colonization; rising inequality; and wars and conflicts over religion and state building.

Along with other metrics, heights are now used to investigate living standards in the pre-industrial world (Allen, Bengtsson et al. 2005). France has the longest height series available for study, which Komlos and co-authors use to monitor living standards in pre-industrial France (Komlos 1995c; Komlos 2003b; Komlos, Hau et al. 2003). Mironov documents that health, as measured by height, stagnated in eighteenth-century Russia despite significant progress in arts, education and science (Mironov 2005).

Additional studies on Europe consider the modern period. Some work has been done on the long height series of France, which illuminate their unusual if not unique path toward industrialization (Heyberger 2006). Studies of Holland show that their remarkable surge toward becoming the tallest in the world by the end of the twentieth century did not begin until the second half of the nineteenth century (de Beer 2004). Research on Eastern Europe indicates that most of the secular increase occurred in the past 125 years (Lintsi and Kaarma 2006; Vignerová, Brabec et al. 2006).

\section{Methods}

As part of the new anthropometric history, scholars paid greater attention to possible biases in data sources and to developing new methods of statistical analysis. Minimum height standards that sometimes changed or were flexibly imposed by military organizations, created an analytical problem. Early approaches, such as the quantile bend estimator, were not very robust. Komlos and collaborators have been innovative in recognizing problems and suggesting solutions (Komlos 2004). More recent approaches include a Bayesian technique to estimate non-parametric additive models (Lang and Sunder 2003). A'Hearn developed the restricted maximum likelihood estimator to contend with small samples where the minimum height requirement is near the mean of the distribution (A'Hearn 2004). Recently he and collaborators formulated a 
semiparametric approach that relaxes the assumption of normality, providing new insights into chronological patterns in the timing of the adolescent growth spurt in Italy (A'Hearn, Peracchi et al. 2009 forthcoming). Lang and Sunder use a Bayesian approach, and the computer program BayesX, to estimate nonparametric additive models (Lang and Sunder 2003). After comparing the performance of various estimators for a height sample from Drenthe, The Netherlands, Jacobs et al. develop an estimator that imposes no distributional restrictions but assumes there is a linear relationship between the proportion of conscripts below the minimum height requirement and the mean of the truncated sample (Jacobs, Katzur et al. 2008).

Two additional papers that can be classified as methods concern the collection and organization of data. Grosh and Glewwe discuss the data gathering activities of the World Bank and specifically the Living Standards Measurement Surveys, which have prompted much anthropometric study in developing countries (Grosh and Glewwe 1995). Steckel converts height data assembled by the National Center for Health Statistics, which are often cited as a global standard, into relatively fine gradations that are useful in calculating precise percentiles of mean heights that are useful in historical work (Steckel 1996)

New types of evidence combined with suitable theoretical and econometric techniques can advance the field. In an interesting study on Russia, Federov and Sahn demonstrate the advantages of panel data for investigating the socioeconomic determinants of child growth (Fedorov and Sahn 2005). They estimate a dynamic health demand function using a generalized method of moments estimator to account for the endogeneity of lagged height in determining health incomes. While economic historians seldom have access to panel data, these methods have something to offer in interpreting results from cross-section studies.

It is difficult to anticipate where methodological developments may go from here. It is clear, however, that the new methods now available have yet to diffuse through practitioners in the field. Perhaps it is time to take stock of the techniques at hand by applying them to a wide range of data sets now available. It is important to know how empirical results and their interpretation differ under these various techniques. 


\section{Wages}

Since 1995 ten papers have appeared on heights as a determinant of wages or income, the majority appearing in economics journals. Development economists have known for some time that taller and stronger men earned more in occupations for which physical strength is an asset. This research continues with studies on coalminers in India (Dinda, Gangopadhyay et al. 2006), workers in Brazil (Thomas and Strauss 1997), and farmers in Ethiopia (Croppenstedt and Muller 2000). Schultz finds an 8 to 10 per cent increase in wages for every centimeter increase in stature of men or women in Ghana and Brazil, if heights are instrumented by availability of private and public inputs to nutrition and health care (Schultz 2002).

In a new direction for this type of research, the majority of papers since 1995 consider the implications of stature and other anthropometric measures for income or wages in developed countries (Meyer and Selmer 1999; Heineck 2005; Rashad 2008). Some papers now investigate the implications not only of height but weight and beauty for labor market remuneration (Harper 2000; Wada and Tekin 2007). Possibly employers discriminate against obese people for higher-paying positions of leadership and decision making in nine European countries (Atella, Pace et al. 2008). In Denmark's private sector, obesity was a disadvantage for women but actually beneficial for men (Greve 2008).

A few years ago Persico et al. suggested that boys who were taller in adolescence gain confidence, social skills and related forms of human capital that serve them well in adult labor markets (Persico, Postlewaite et al. 2004). The most recent strand of this research argues that taller people earn more because they have greater cognitive ability. Case and Paxson challenge the Persico et al. mechanism linking stature to higher wages, showing that people who were tall as adolescents were also tall and did well on cognitive tests in early childhood, before schooling could have selectively boosted their human capital (Case and Paxson 2008b). The benefits of robust physical growth in childhood extend into adulthood as reflected in better cognitive function, improved mental health and ability to perform activities of daily living (Case 
and Paxson 2008a). This finding has several implications, including an explanation for why economic returns to height continue to be observed in wealthy countries. It also demonstrates the long reach into adulthood of early childhood conditions, suggesting that societies probably under invest in pre-natal and early childhood health and nutrition.

If confirmed by other studies, the mechanism outlined by Case and Paxson will have considerable influence on economic history, economic development and our understanding of the sources of economic growth. It will bring nutritional status and stature to the fore in comprehending rates of return to schooling, socioeconomic inequality that stems from cognitive deficits, and conceivably rates of technological change. One could imagine dissertations on whether nutritional improvements helped trigger the Enlightenment or whether increases in agricultural productivity, which preceded or accompanied industrialization in many countries, also contributed to economic growth via more effective decision making. At this point I am not convinced that such studies are warranted but the speculations are useful as an exercise in pondering the testable implications of the link between nutrition and cognition.

\section{Concluding Remarks}

This review demonstrates that anthropometric history and now anthropometric research of many kinds are vigorous areas of study. Since 1995 analyses of stature and related anthropometric measures have appeared in approximately 325 publications within the social sciences. Much of this work investigates research and policy questions beyond the traditional bailiwick of anthropometric history, including biological welfare during economic and political crises; anthropometric determinants of wages; the welfare of women relative to men in the contemporary world; the fetal origins hypothesis; and inequality in the developing world. The approach has also expanded within economic history to consider the consequences of empire for colonials; the health of populations lacking traditional measures of social performance; the consequences of smallpox; and very long-term trends in health. Much has also been learned about socioeconomic aspects of inequality, the welfare implications of industrialization, and socioeconomic determinants of stature. The last is a work in progress and one may doubt whether 
sufficient longitudinal evidence will become available for a complete understanding of the variety and strength of pathways that affect human physical growth.

It is heartening that economists are integrated into the field and no longer need to explain their methods in papers accepted by general-interest economics journals. On the other hand, it is unfortunate that some areas of the social sciences publish little height research despite its promise to advance knowledge of their core questions. Perhaps sociologists and political scientists are unaware of the potential of using heights for studying inequality, socioeconomic performance, gender disparities, healthcare needs, and the like. Maybe fixed costs of learning the relevant human biology is an obstacle, and few researchers are willing to invest until a critical mass of fellow travelers is engaged in dialogue.

The intellectual history of the new anthropometric history, and similar experiences in other disciplines, demonstrate that new methods often meet skepticism if not outright resistance. Those who challenge the status quo face a large body of literature that has already defined important research questions and acceptable approaches. New methods requiring unfamiliar data sources must address important topics in which there is already an established interest, confirming some beliefs that are well established while providing new, plausible results on others. Hopefully other areas of the social sciences are approaching this transition.

A vast and growing collection of data is encouraging news. Like historians in general, anthropometric historians have mined the archives and have coded millions of observations on height, including nearly ten million in Columbia alone. People were regularly measured for identification purposes on sources such as ID cards, slave manifests, prison records, muster rolls, and so forth. With these resources scholars have investigated the anthropometric histories of dozens of countries and new studies appear on a regular basis. By the 1980s household surveys in numerous developing countries regularly included anthropometric information along with various socioeconomic variables. Several developed countries also collect height and weight data to monitor health, illustrated by the National Health and Nutrition Examination Survey and the National Longitudinal Survey of Youth in the United States; the German 
Socio-Economic Panel; and the social indicators report of the OECD (Society at a Glance). Given the cost-effectiveness of height data, more evidence should be collected to identify and target treatment for groups at risk in high-income countries.

Analysis of health indicators found on archaeological skeletons is an important new frontier of anthropometric research. Such remains provide far more information on health than stature alone. They contain life-cycle information, including childhood indicators such as stature (inferred from femur length) and tooth enamel deformities, indicators of aging such as degenerative joint disease and dental decay, as well as information on trauma, infections and specific diseases such as TB and syphilis. Perhaps one to two million individuals are available for study in various museums across the globe, furnishing biological perspective on health during the major transitions in human history such as the rise of agriculture and pastoralism; the emergence of cities; global exploration and colonization, and industrialization. Accompanied by ecological and socioeconomic context, these materials enable researchers to investigate important aspects of social performance within the deep history of human civilization. 


\section{References}

A'Hearn, Brian (2003). "Anthropometric Evidence on Living Standards in Northern Italy, 1730-1860." Journal of Economic History 63(2): 351-381.

A'Hearn, Brian (2004). "A Restricted Maximum Likelihood Estimator for Truncated Height Samples." Economics and Human Biology 2(1): 5-19.

A'Hearn, Brian (2006). "Remapping Italy's Path to the XIXth Century: Anthropometric Signposts." Journal of European Economic History 35(2): 349-392.

A'Hearn, Brian, Franco Peracchi, et al. (2009 forthcoming). "Height and the Normal Distribution: Evidence from Italian Military Data." Demography 46(1).

Akachi, Yoko and David Canning (2007). "The Height of Women in Sub-Saharan Africa: The Role of Health, Nutrition, and Income in Childhood." Annals of Human Biology 34(4): 397-410.

Alderman, Harold, John Hoddinott, et al. (2006). "Long Term Consequences of Early Childhood Malnutrition." Oxford Economic Papers 58(3): 450-474.

Alderman, Harold, Hans Hoogeveen, et al. (2006). "Reducing Child Malnutrition in Tanzania: Combined Effects of Income Growth and Program Interventions." Economics and Human Biology 4(1): 1-23.

Alderman, Harold, Hans Hoogeveen, et al. (2009). "Preschool Nutrition and Subsequent Schooling Attainment: Longitudinal Evidence from Tanzania." Economic Development and Cultural Change 57(2): 239-60.

Allen, Robert C., Tommy Bengtsson, et al., Eds. (2005). Living Standards in the Past: New Perspective on Well-Being in Asia and Europe. Oxford, Oxford University Press.

Almond, Douglas (2006). "Is the 1918 Influenza Pandemic Over? Long-Term Effects of in Utero Influenza Exposure in the Post-1940 U.S. Population." Journal of Political Economy 114(4): 672-712.

Almond, Douglas and Bhashkar Mazumder (2005). "The 1918 Influenza Pandemic and Subsequent Health Outcomes: An Analysis of SIPP Data." American Economic Review 95(2): 258-262.

Alter, George (2004). "Height, Frailty, and the Standard of Living: Modeling the Effects of Diet and Disease on Declining Mortality and Increasing Height." Population Studies 58(3): 265-279.

Alter, George, Muriel Neven, et al. (2004). "Stature in Transition - a Micro-Level Study from Nineteenth-Century Belgium." Social Science History 28(2): 231-247.

Alter, George and Michel Oris (2008). "Effects of Inheritance and Environment on the Heights of Brothers in Nineteenth-Century Belgium." Human Nature 19(1): 44-55.

Alves, Denisard and Walter Belluzzo (2004). "Infant Mortality and Child Health in Brazil." Economics and Human Biology 2(3): 391-410.

Ambadekar, N.N., S.N. Wahab, et al. (1999). "Effect of Child Labour on Growth of Children." Public Health 113(6): 303-06.

Arcaleni, Emilia (2006). "Secular Trend and Regional Differences in the Stature of Italians, 1854-1980." Economics and Human Biology 4(1): 24-38. 
Arora, Suchit (2001). "Health, Human Productivity, and Long-Term Economic Growth." Journal of Economic History 61(3): 699-749.

Atella, Vincenzo, Noemi Pace, et al. (2008). "Are Employers Discriminating with Respect to Weight? European Evidence Using Quantile Regression." Economics and Human Biology 6(3): 305-29.

Attanasio, Orazio, Luis Carlos Gomez, et al. (2004). "Child Health in Rural Columbia: Determinants and Policy Interventions." Economics and Human Biology 2(3): 411-38.

Ayalew, Tekabe (2005). "Parental Preference, Heterogeneity, and Human Capital Inequality." Economic Development and Cultural Change 53(2): 381-407.

Baltzer, Markus and Jörg Baten (2008). "Height, Trade, and Inequality in the Latin American Periphery, 1950-2000." Economics and Human Biology 6(2): 191-203.

Banerjee, Abhijit, Esther Duflo, et al. (2007). Long Run Health Impacts of Income Shocks: Wine and Phylloxera in 19th Century France NBER Working Paper No. W12895. Cambridge.

Barker, David J. P. (1994). Mothers, Babies and Disease in Later Life. London, BMJ Publishing Group.

Bassino, Jean-Pascal (2006). "Inequality in Japan (1892-1941): Physical Stature, Income and Health." Economics and Human Biology 4(1): 62-88.

Bassino, Jean-Pascal and Peter A. Coclanis (2008). "Economic Transformation and Biological Welfare in Colonial Burma: Regional Differentiation in the Evolution of Average Height." Economics and Human Biology 6(2): 212-27.

Baten, Jörg, Dorthee Crayen, et al. (2008). Poor, Hungary and Stupid: Numeracy and the Poor Law in Britain, 1780-1850. Tübingen.

Baten, Jörg and John E. Murray (1997). "Bastardy in South Germany Revisited: An Anthropometric Synthesis." Journal of Interdisciplinary History 28(1): 47-56.

Baten, Jörg and John E. Murray (1998). "Women's Stature and Marriage Markets in Preindustrial Bavaria." Journal of Family History 23(2): 124-35.

Baten, Jörg and John E. Murray (2000). "Heights of Men and Women in 19th-Century Bavaria: Economic, Nutritional, and Disease Influences." Explorations in Economic History 37(4): 351-69.

Baten, Jörg and Andrea Wagner (2003). "Autarky, Market Disintegration, and Health: The Mortality and Nutritional Crisis in Nazi Germany, 1933-37." Economics and Human Biology 1(1): 1-28.

Behrman, Jere R. and Emmanuel Skoufias (2004). "Correlates and Determinants of Child Anthropometrics in Latin America: Background and Overview of the Symposium." Economics and Human Biology 2(3): 335-51.

Berkhofer, Robert F. Jr. (1988). White Conceptions of Indians. History of Indian-White Relations, Vol. 4 of Handbook of North American Indians. W. E. Washburn. Washington, Smithsonian: 522-47.

Bhattacharyya, Amiya Kumar (2006). "Composite Index of Anthropometric Failure (CIAF) Classification: Is It More Useful?" Bulletin of the World Health Organization 84(4): 335-336.

Blackwell, D. L., M. D. Hayward, et al. (2001). "Does Childhood Health Affect Chronic Morbidity in Later Life?" Social Science and Medicine 52(8): 1269-1284. 
Bodenhorn, Howard (1999). "A Troublesome Caste: Height and Nutrition of Antebellum Virginia's Rural Free Blacks." Journal of Economic History 59(4): 972-996.

Bodenhorn, Howard (2002). "The Mulatto Advantage: The Biological Consequences of Complexion in Rural Antebellum Virginia." Journal of Interdisciplinary History 33(1): 21-46.

Böetsch, Gilles, Aude Brus, et al. (2008). "Stature, Economy and Migration During the 19th Century: Comparative Analysis of Haute-Vienne and Hautes-Alpes, France." Economics and Human Biology 6(1): 170-180.

Bogin, Barry (2001). The Growth of Humanity. New York, Wiley-Liss.

Bozić-Krstić, V.S., T.M. Pavlica, et al. (2004). "Body Height and Weight of Children in Novi Sad." Annals of Human Biology 31(3): 356-363.

Bozzoli, Carlos, Angus S. Deaton, et al. (2007). Child Mortality, Income and Adult Height NBER Working Paper No. 12966. Cambridge.

Brainerd, Elizabeth (2006). Reassessing the Standard of Living in the Soviet Union: An Analysis Using Archival and Anthropometric Data. CEPR Discussion Paper No. 5525. London.

Brennan, Lance and John McDonald (2001). "The 'Inverted U' Hypothesis: Evidence from Indian Height Data." Journal of Income Distribution 10(3/4): 77.

Brennan, Lance, John McDonald, et al. (1995). "Long-Term Change and Sex Differences in the Heights of Afro-Caribbeans and Indo-Caribbeans." Social and Economic Studies 44(1): 73-93.

Brennan, Lance, John McDonald, et al. (1997). "Towards an Anthropometric History of Indians under British Rule." Research in Economic History 17: 185-246.

Cameron, Noël (2003). "Physical Growth in a Transitional Economy: The Aftermath of South African Apartheid." Economics and Human Biology 1(1): 29-42.

Carrión, José M. Martínez and Juan J. Pérez Castejón (1998). "Height and Standards of Living During the Industrialisation of Spain: The Case of Elche." European Review of Economic History 2(2): 201-230.

Carson, Scott A. (2009 forthcoming-a). "African-American and White Inequality in the Nineteenth-Century American South: A Biological Comparison." Journal of Population Economics.

Carson, Scott Alan (2005). "The Biological Standard of Living in 19th Century Mexico and in the American West." Economics and Human Biology 3(3): 405-419.

Carson, Scott Alan (2008a). "The Effect of Geography and Vitamin D on African American Stature in the Nineteenth Century: Evidence from Prison Records." Journal of Economic History 68(3): 812-31.

Carson, Scott Alan (2008b). "Health During Industrialization: Evidence from the Nineteenth-Century Pennsylvania State Prison System." Social Science History 32(3): 347-72.

Carson, Scott Alan (2008c). "Inequality in the American South: Evidence from the Nineteenth Century Missouri State Prison." Journal of Biosocial Science 40: 587605.

Carson, Scott Alan (2008d). "The Stature and Body Mass of Mexicans in the Nineteenth-Century United States." Journal of Interdisciplinary History 39(2): 211-32. 
Carson, Scott Alan (2009). "Geography, Insolation, and Vitamin D in Nineteenth Century U.S. African-American and White Statures." Explorations in Economic History 46(1).

Carson, Scott Alan (2009 forthcoming-b). "Health, Wealth and Inequality: A Contribution to the Debate About the Relationship between Inequality and Health." Historical Methods (42).

Case, Anne and Christina Paxson (2008a). "Height, Health, and Cognitive Function at Older Ages." American Economic Review: Papers \& Proceedings 98(2): 463-67.

Case, Anne and Christina Paxson (2008b). "Stature and Status: Height, Ability, and Labor Market Outcomes " Journal of Political Economy 116(3): 499-532.

Cavelaars, A.E., A.E. Kunst, et al. (2000). "Persistent Variations in Average Height between Countries and between Socio-Economic Groups: An Overview of 10 European Countries." Annals of Human Biology 27(4): 407-21.

Chakravarty, Satya R. and Amita Majumder (2005). "Measuring Human Poverty: A Generalized Index and an Application Using Basic Dimensions of Life and Some Anthropometric Indicators." Journal of Human Development 6(3): 275-299.

Chanda, Areendam, Lee A. Craig, et al. (2008). "Convergence (and Divergence) in the Biological Standard of Living in the United States, 1820-1900." Cliometrica 2(1): 19-48.

Chaudhuri, Anoshua (2008). "Revisiting the Impact of a Reproductive Health Intervention on Children's Height-for-Age with Evidence from Rural Bangladesh." Economic Development and Cultural Change 56(3): 619-56.

Chilima, Dorothy (2000). "Assessing Nutritional Status and Functional Ability of Older Adults in Developing Countries." Development in Practice 10(1): 108-113.

Christensen, T. L., C. B. Djurhuus, et al. (2007). "An Evaluation of the Relationship between Adult Height and Health-Related Quality of Life in the General UK Population." Clinical Endocrinology 67(3): 407-412.

Christiaensen, Luc and Harold Alderman (2004). "Child Malnutrition in Ethiopia: Can Maternal Knowledge Augment the Role of Income?" Economic Development and Cultural Change 52(2): 287-312.

Cinnirella, Francesco (2008a). "On the Road to Industrialization: Nutritional Status in Saxony, 1690-1850 " Cliometrica 2(3): 229-57.

Cinnirella, Francesco (2008b). "Optimists or Pessimists?: A Reconsideration of Nutritional Status in Britain, 1740-1865." European Review of Economic History 12(3): 325-54.

Coatsworth, John H. (1996). "Welfare." American Historical Review 101(1): 1-12.

Coclanis, Peter A. and John Komlos (1995). "Nutrition and Economic Development in Post-Reconstruction South Carolina: An Anthropometric Approach." Social Science History 19(1): 91-115.

Coelho, Philip R. P. and Robert A. McGuire (2000). "Diets Versus Diseases: The Anthropometrics of Slave Children." Journal of Economic History 60(1): 232-46.

Cortez, Solange Aparecida Estevão, Marco Antonio Barbieri, et al. (2007). "Does Child Labor Affect Final Height?" Occupational Medicine 10(2): 118-25.

Costa-Font, Joan and Joan Gil (2008). "Generational Effects and Gender Height Dimorphism in Contemporary Spain." Economics and Human Biology 6(1): 1-18. 
Costa, Dora L. (1998). "Unequal at Birth: A Long-Term Comparison of Income and Birth Weight." Journal of Economic History 58(4): 987-1009.

Costa, Dora L. (2004). "The Measure of Man and Older Age Mortality: Evidence from the Gould Sample " Journal of Economic History 64(1): 1-23.

Costa, Dora L. and Richard H. Steckel (1997). Long-Term Trends in Health, Welfare, and Economic Growth in the United States. Health and Welfare During Industrialization. R. H. Steckel and R. Floud. Chicago, University of Chicago Press: 47-89.

Crafts, N. F. R. (1997). "Some Dimensions of the 'Quality of Life' During the British Industrial Revolution." Economic History Review 50(4): 617-39.

Craig, Lee A., Barry Goodwin, et al. (2004). "The Effect of Mechanical Refrigeration on Nutrition in the United States." Social Science History 28(2): 325-36.

Cranfield, J. and K. Inwood (2007). "The Great Transformation: A Long-Run Perspective on Physical Well-Being in Canada." Economics and Human Biology 5(2): 204228.

Crimmins, E.M. and C.E. Finch (2006). "Infection, Inflammation, Height, and Longevity." Proceedings of the National Academy of Science 103(2): 498-503.

Croppenstedt, Andre and Christophe Muller (2000). "The Impact of Farmers' Health and Nutritional Status on Their Productivity and Efficiency: Evidence from Ethiopia." Economic Development and Cultural Change 48(3): 475-502.

Cuff, Timothy (2005). The Hidden Cost of Economic Development: The Biological Standard of Living in Antebellum Pennsylvania. Burlington, Vt., Ashgate Publishing.

Cutler, David M, Angus S. Deaton, et al. (2006). The Determinants of Mortality NBER Working Paper No. 11963. Cambridge.

Cvrcek, Tomas (2006). "Seasonal Anthropometric Cycles in a Command Economy: The Case of Czechoslovakia, 1946-1966." Economics and Human Biology 4(3): 31741.

Dangour, A.D., A. Farmer, et al. (2003). "Anthropometric Status of Kazakh Children in the 1990s." Economics and Human Biology 1(1): 43-53.

Danubio, Maria Enrica, et al. (2005). "Height and BMI of Italian Immigrants to the USA, 1908-1970." Economics and Human Biology 3(1): 33-43.

Dasgupta, Parasmani, Rana Saha, et al. (2008). "Changes in Body Size, Shape and Nutritional Status of Middle-Class Bengali Boys of Kolkata, India, 1982-2002." Economics and Human Biology 6(1): 75-94.

David, Vincent, Nincadam Narci, et al. (2004). "Private and Public Determinants of Child Nutrition in Nicaragua and Western Honduras." Economics and Human Biology 2(3): 457-88.

De Beer, Hans (2004). "Observations on the History of Dutch Physical Stature from the Late-Middle Ages to the Present." Economics and Human Biology 2(1): 45-55.

De Onis, Mercedes and Monika Blössner (2003). "The World Health Organization Global Database on Child Growth and Malnutrition: Methodology and Applications." International Journal of Epidemiology 32(4): 518-26. 
De Souza, Roberta G. (2006). "Body Size and Growth: The Significance of Chronic Malnutrition among the Casiguran Agta." Annals of Human Biology 33(5-6): 604619.

Deaton, Angus (2007). "Height, Health, and Development." Proceedings of the National Academy of Sciences 104(33): 13232-37.

Deaton, Angus (2008). "Height, Health, and Inequality: The Distribution of Adults Heights in India." American Economic Review: Papers \& Proceedings 98(2): 46874.

Deaton, Angus (2003). "Health, Inequality, and Economic Development " Journal of Economic Literature 41(1): 113-58.

Delajara, Marcelo (2004). "Economic Development and the Quality of Life of Children." Revista de Historia Economica 22(1): 13-38.

Dick, Trevor (1995). Heights, Nutrition, and Per Capita Income: Canada, 1870-1915. The Biological Standard of Living on Three Continents: Further Explorations in Anthropometric History. J. Komlos. Boulder, Westview Press: 123-131.

Dinda, Soumyananda, P.K. Gangopadhyay, et al. (2006). "Height, Weight and Earnings among Coalminers in India." Economics and Human Biology 4(3): 342-50.

Drukker, J.W. and Vincent Tassenaar (1997). Paradoxes of Modernization and Material Well-Being in the Netherlands During the Nineteenth Century. Health and Welfare During Industrialization. R. H. Steckel and R. Floud. Chicago, University of Chicago Press: 331-377.

Drukker, Jan W. and Michiel A. Van Meerten (1995). Beyond Villermé and Quetelet: The Quantitative Relation between Sex- and Age-Specific Height and Real Per Capita Income. The Biological Standard of Living on Three Continents: Further Explorations in Anthropometric History. J. Komlos. Boulder, Westview Press: 2557.

Duflo, Esther (2003). "Grandmothers and Granddaughters: Old Age Pensions and IntraHousehold Allocations in South Africa." World Bank Economic Review 17(1): 125.

Dye, Ira (1995). Heights of Early American Seafarers, 1812-1815. The Biological Standard of Living on Three Continents: Further Explorations in Anthropometric History. J. Komlos. Boulder, Westview Press: 95-104.

Easterlin, Richard A. (1999). "How Beneficent Is the Market? A Look at the Modern History of Mortality." European Review of Economic History 3(3): 257-94.

Easterlin, Richard A. (2000). "The Worldwide Standard of Living since 1800." Journal of Economic Perspectives 14(1): 7-26.

Engerman, Stanley (1997). The Standard of Living Debate in International Perspective: Measures and Indicators. Health and Welfare During Industrialization. R. H. Steckel and R. Floud. Chicago, University of Chicago Press: 17-45.

Eveleth, Phyllis B. and James M. Tanner (1976, 1990). Worldwide Variation in Human Growth Cambridge, Cambridge University Press.

Ewert, Ulf Christian (2006). "The Biological Standard of Living on the Decline: Episodes from Germany During Early Industrialisation." European Review of Economic History 10(1): 51-88. 
Federico, Giovanni (2003). "Heights, Calories and Welfare: A New Perspective on Italian Industrialization, 1854-1913." Economics and Human Biology 1(3): 289308.

Fedorov, Leonid and David E. Sahn (2005). "Socioeconomic Determinants of Children's Health in Russia: A Longitudinal Study." Economic Development and Cultural Change 53(2): 479-500.

Feinstein, Charles H. (1998). "Pessimism Perpetuated: Real Wages and the Standard of Living in Britain During and after the Industrial Revolution." Journal of Economic History 58(3): 625-658.

Floud, Roderick and Bernard Harris (1997). Health, Height, and Welfare: Britain, 17001980. Health and Welfare During Industrialization. R. H. Steckel and R. Floud. Chicago, University of Chicago Press: 91-126.

Fogel, Robert W. (2004a). The Escape from Hunger and Premature Death, 1700-2100. New York, Cambridge University Press.

Fogel, Robert W. (2004b). "Health, Nutrition, and Economic Growth." Economic Development and Cultural Change 52(3): 643-658.

Fogel, Robert W. and Dora L. Costa (1997). "A Theory of Technophysio Evolution, with Some Implications for Forecasting Population, Health Care Costs, and Pension Costs." Demography 34(1): 49-66.

Frank, Zephyr (2006). "Stature in Nineteenth-Century Rio De Janeiro: Preliminary Evidence from Prison Records." Revista de Historia Economica 24(3): 465-489.

Gage, Timothy B. and Shelly M. Zansky (1995). "Anthropometric Indicators of Nutritional Status and Level of Mortality." American Journal of Human Biology 7(6): 679691.

Gaiha, Raghav and Veena Kulkarni (2005). "Anthropometric Failure and Persistence of Poverty in Rural India." International Review of Applied Economics 19(2): 179197.

Galiani, Sebastian and Ernesto Schargrodsky (2004). "Effects of Land Titling on Child Health." Economics and Human Biology 2(3): 353-72.

Gallman, Robert E. (1996). "Dietary Change in Antebellum America." Journal of Economic History 56(1): 193-201.

Gertler, Paul (2004). "Do Conditional Cash Transfers Improve Child Health? Evidence from Progresa's Control Randomized Experiment." American Economic Review 94(2): 336-341.

Ghuman, Sharon, Jere R. Behrman, et al. (2005). "Family Background, Service Providers, and Early Childhood Development in the Philippines: Proxies and Interactions." Economic Development and Cultural Change 54(1): 129-164.

Gibson, John and Scott Rozelle (2003). "Poverty and Access to Roads in Papua New Guinea." Economic Development and Cultural Change 52(1): 159-185.

Godoy, Ricardo A., William R. Leonard, et al. (2006). "Physical Stature of Adult Tsimane' Amerindians, Bolivian Amazon in the 20th Century." Economics and Human Biology 4(2): 184-205.

Godoy, Ricardo A., Victoria Reyes-Garcia, et al. (2005). "Human Capital, Wealth, and Nutrition in the Bolivian Amazon." Economics and Human Biology 3(1). 
Gomez-Mendoza, A. and V. Perez-Moreda (1995). Heights and Welfare in Spain, 19001930. The Biological Standard of Living on Three Continents: Further

Explorations in Anthropometric History. J. Komlos. Boulder, Westview Press: 8191.

Greve, Jane (2008). "Obesity and Labor Market Outcomes in Denmark." Economics and Human Biology 6(3): 350-62.

Grosh, Margaret E. and Paul Glewwe (1995). A Guide to Living Standards Measurement Study Surveys and Their Data Sets. LSMS Working Paper No. 120. Washington, DC, World Bank.

Grubb, Farley (1999a). "Lilliputians and Brobdingnagians, Stature in British Colonial America: Evidence from Servants, Convicts, and Apprentices." Research in Economic History 19: 139-203.

Grubb, Farley (1999b). "Withering Heights: Did Indentured Servants Shrink from an Encounter with Malthus? A Comment on Komlos." Economic History Review 52(4): 714-729.

Guntupalli, Aravinda Meera and Joerg Baten (2006). "The Development and Inequality of Heights in North, West, and East India 1915-1944." Explorations in Economic History 43(4).

Gyenis, Gyula and Kálmán Joubert (2004). "Socioeconomic Determinants of Anthropometric Trends among Hungarian Youth." Economics and Human Biology 2(2): 321-33.

Gylfason, Thorvaldur (2007). "Why Europe Works Less and Grows Taller." Challenge 50(1): 21-39.

Hacker, J. David (2008). "Economic, Demographic, and Anthropometric Correlates of First Marriage in the Mid-Nineteenth Century United States." Social Science History 32(3): 307-45.

Haines, M. R., L. A. Craig, et al. (2003). "The Short and the Dead: Nutrition, Mortality, and The "Antebellum Puzzle" In the United States." Journal of Economic History 63(2): 382-413.

Haines, Michael R. (2004). "Growing Incomes, Shrinking People - Can Economic Development Be Hazardous to Your Health? Historical Evidence for the United States, England, and the Netherlands in the Nineteenth Century." Social Science History 28(2): 249-270.

Haines, Michael R. and Hallie J. Kitner (2008). "Can Breast Feeding Help You in Later Life? Evidence from German Military Heights in the Early 20th Century." Economics and Human Biology 6(3): 420-30.

Haines, Michael R. and Richard H. Steckel (2000). "Childhood Mortality and Nutritional Status as Indicators of Standard of Living: Evidence from World War I Recruits in the United States." Jahrbuch für Wirtschafts Geschichte(1): 49-53.

Hall, Stephen S. (2006). Size Matters: How Height Affects the Health, Happiness, and Success of Boys - and the Men They Become. New York, Houghton Mifflin.

Handa, Sudhanshu (1999). "Maternal Education and Child Height." Economic Development and Cultural Change 47(2): 421-39.

Harper, Barry (2000). "Beauty, Stature and the Labour Market: A British Cohort Study." Oxford Bulletin of Economics and Statistics 62(s1): 771-800. 
Harris, Bernard (1997). "Growing Taller, Living Longer? Anthropometric History and the Future of Old Age." Ageing and Society 17(5): 491-512.

Haughton, Dominique and Jonathan Haughton (1997). "Explaining Child Nutrition in Vietnam." Economic Development and Cultural Change 45(3): 541-556.

Hawamdeh, H. and N. Spencer (2003). "Effect of Work Related Variables on Growth among Working Boys in Jordan." Journal of Epidemiology and Community Health 57(2): 154-58.

Heckman, James J. (2006). "Skill Formation and the Economics of Investing in Disadvantaged Children." Science 312(30 June): 1900-02.

Heineck, Guido (2005). "Up in the Skies? The Relationship between Body Height and Earnings in Germany." Labour 19(3): 469-489.

Heineck, Guido (2006). "Height and Weight in Germany, Evidence from the German Socio-Economic Panel, 2002." Economics and Human Biology 4(3): 359-382.

Heintel, Markus and Joerg Baten (1998). "Smallpox and Nutritional Status in England, 1770-1873: On the Difficulties of Estimating Historical Heights." Economic History Review 51(2): 360-71.

Hendriks, Sheryl (2005). "The Challenges Facing Empirical Estimation of Household Food (in)Security in South Africa." Development Southern Africa 22(1): 103 123.

Henriksson, Karin M., U. Lindblad, et al. (2001). "Associations between Body Height, Body Composition and Cholesterol Levels in Middle-Aged Men. The Coronary Risk Factor Study in Southern Sweden (CRISS)." European Journal of Epidemiology 17(6): 521-526.

Heyberger, L. (2007). "Toward an Anthropometric History of Provincial France, 17801920." Economics and Human Biology 5(2): 229-254.

Heyberger, Laurent (2006). "Évolution De La Stature Moyenne Considérée Comme Indice De Niveau De Vie Biologique Dans Trois Régions Françaises, 1780-1940. (Evolution of Mean Height as an Index of the Biological Standard of Living in Three French Regions, 1780-1940)." Economies et Societes 35(8): 1031-1052.

Hiermeyer, Martin (2008). "The Trade-Off between a High and an Equal Biological Standard of Living--Evidence from Germany." Economics and Human Biology 6(3): 431-45.

Hoch, Steven L. (1999). "Tall Tales: Anthropometric Measures of Well-Being in Imperial Russia and the Soviet Union, 1821-1960." Slavic Review 58(1): 61-70.

Hoddinott, John (2006). "Shocks and Their Consequences across and within Households in Rural Zimbabwe." Journal of Development Studies 42(2): 301 321.

Honda, Gail (1997). Differential Structure, Differential Health: Industrialization in Japan, 1868-1940. Health and Welfare During Industrialization. R. H. Steckel and R.

Floud. Chicago, University of Chicago Press: 251-84.

Horrell, Sara H., David G. Meredith, et al. (2009). "Measuring Misery: Body Mass, Ageing and Gender Inequality in Victorian London." Explorations in Economic History 46(1).

Humphries, Jane (1997). "Short Stature among Coal-Mining Children: A Comment." Economic History Review 50(3): 531-7. 
Humphries, Jane and Timothy Leunig (2009a). "Cities, Market Integration and Going to Sea: Stunting and the Standard of Living in Earlly Nineteenth Century England and Wales." Economic History Review 49.

Humphries, Jane and Timothy Leunig (2009b). "Was Dick Whittington Taller Than Those He Left Behind? Anthropometric Measures, Migration and the Quality of Life in Early Nineteenth Century London?" Explorations in Economic History 46(1).

Jackson, R. V. (1996). "The Heights of Rural-Born English Female Convicts Transported to New South Wales." Economic History Review 49(3): 584-590. Jackson, R. V. and Mark Thomas (1995). "Height, Weight, and Wellbeing: Sydney Schoolchildren in the Early Twentieth Century." Australian Economic History Review 35(2): 39-65.

Jacobs, Jan, Tomek Katzur, et al. (2008). "On Estimators for Truncated Height Samples." Economics and Human Biology 6(1): 43-56.

Jacobs, Jan and Vincent Tassenaar (2004). "Height, Income, and Nutrition in the Netherlands: The Second Half of the 19th Century." Economics and Human Biology 2(2): 181-95.

Johnson, Paul and Stephen Nicholas (1995). "Male and Female Living Standards in England and Wales, 1812-1857: Evidence from Criminal Height Records." Economic History Review 48(3): 470-81.

Johnson, Paul and Stephen Nicholas (1997). Health and Welfare of Women in the United Kingdom, 1785-1920. Health and Welfare During Industrialization. R. H. Steckel and R. Floud. Chicago, University of Chicago Press: 201-49.

Jousilahti, Pekka, Jaakko Tuomilehto, et al. (2000). "Relation of Adult Height to CauseSpecific and Total Mortality: A Prospective Follow-up Study of 31, 199 MiddleAged Men and Women in Finland " American Journal of Epidemiology 151(11): $1112-1120$

Kirby, Peter (1995). "Causes of Short Stature among Coal-Mining Children, 1823-1850." Economic History Review 48(4): 687-99

Kirby, Peter (1997). "Short Stature among Coal-Mining Children: A Rejoinder." Economic History Review 50(3): 538-42.

Koepke, Nikola and Joerg Baten (2008). "Agricultural Specialization and Height in Ancient and Medieval Europe." Explorations in Economic History 45(2).

Koepke, Nikola and Joerg Baten (2005). "The Biological Standard of Living in Europe During the Last Two Millenni." European Review of Economic History 9: 61-95.

Komlos, John, Ed. (1995a). The Biological Standard of Living in Europe and America, 1700-1900 : Studies in Anthropometric History Brookfield, Vt., Variorum.

Komlos, John (1995b). "De L'importance De L'histoire Anthropométrique." Annales De Démographie Historique: 211-223.

Komlos, John (1995c). "Le Statut Nutritionnel Des Eleves De L'ecole Polytechnique (the Nutritional Status of Pupils at the Ecole Polytechnique)." Histoire, Economie et Société 14(3): 463-477.

Komlos, John (1996). "Anomalies in Economic History: Toward a Resolution of The "Antebellum Puzzle"." Journal of Economic History 56(1): 202-14. 
Komlos, John (1998). "Shrinking in a Growing Economy? The Mystery of Physical Stature During the Industrial Revolution." Journal of Economic History 58(3): 779802.

Komlos, John (1999). "On the Biological Standard of Living in Russia and the Soviet Union." Slavic Review 58(1): 71-79.

Komlos, John (2001). "On the Biological Standard of Living of Eighteenth-Century Americans: Taller, Richer, Healthier." Research in Economic History 20: 223-248.

Komlos, John (2003a). "Access to Food and the Biological Standard of Living: Perspectives on the Nutritional Status of Native Americans." American Economic Review 93(1): 252-55.

Komlos, John (2003b). "Histoire Anthropometrique: Bilan De Deux Decennies De Recherche. (Anthropometric History: The Achievements of Two Decades of Research. With English Summary.)." Economies et Societes 37(1): 1-24.

Komlos, John (2004). "How to (and How Not to) Analyze Deficient Height Samples - an Introduction." Historical Methods 37(4): 160-173.

Komlos, John (2006). "The Height Increments and BMI Values of Elite Central European Children and Youth in the Second Half of the 19th Century." Annals of Human Biology 33(3): 309-318.

Komlos, John (2007a). "Anthropometric Evidence on Economic Growth, Biological WellBeing and Regional Convergence in the Habsburg Monarchy, C. 1850-1910." Cliometrica 1(3): 211-37.

Komlos, John (2007b). "On English Pygmies and Giants: The Physical Stature of English Youth in the Late-18th and Early-19th Centuries." Research in Economic History 25: 149-68.

Komlos, John (2008). "Stagnation of Heights among Second-Generation U.S.-Born Army Personnel." Social Science Quarterly 89(2): 445-55.

Komlos, John and Bjorn Alecke (1996). "The Economics of Antebellum Slave Heights Reconsidered." Journal of Interdisciplinary History 26(3): 437-57.

Komlos, John and Jörg Baten, Eds. (1998). The Biological Standard of Living in Comparative Perspective. Stuttgart, Franz Steiner Verlag.

Komlos, John and Marieluise Baur (2004). "From the Tallest to (One of) the Fattest: The Enigmatic Fate of the American Population in the 20th Century " Economics and Human Biology 2(1): 54-74.

Komlos, John and Peter A. Coclanis (1997). "On the Puzzling Cycle in the Biological Standard of Living: The Case of Antebellum Georgia." Explorations in Economic History 34(4): 433-59.

Komlos, John and Timothy Cuff, Eds. (1998). Classics of Anthropometric History: A Selected Anthology. St. Katharinen, Scripta Mercaturae Verlag.

Komlos, John H., Ed. (1995d). The Biological Standard of Living on Three Continents: Further Explorations in Anthropometric History. Boulder, Westview Press.

Komlos, John, Michel Hau, et al. (2003). "An Anthropometric History of Early-Modern France." European Review of Economic History 7(2): 159-189.

Komlos, John and Markus Heintel (1999). "The Threat of a Malthusian Crisis in the Habsburg Monarchy." Journal of Interdisciplinary History 30(1): 91-98. 
Komlos, John and Peter Kriwy (2002). "Social Status and Adult Heights in the Two Germanies." Annals of Human Biology 29(6): 641-648.

Komlos, John and Peter Kriwy (2003). "The Biological Standard of Living in the Two Germanies." German Economic Review 4(4): 459-473.

Komlos, John and Benjamin E. Lauderdale (2007). "Underperformance in Affluence: The Remarkable Relative Decline in American Heights in the Second Half of the 20th-Century." Social Science Quarterly 88(2): 283-305.

Komlos, John and Albrecht Ritschl (1995). "Holy Days, Work Days, and the Standard of Living in the Habsburg Monarchy." Journal of Interdisciplinary History 26(1): 5766.

Kopczynski, Michal (2007). "Agrarian Reforms, Agrarian Crisis and the Biological Standard of Living in Poland, 1844-1892." Economics and Human Biology 5(3): 458-470.

Lang, Stefan and Marco Sunder (2003). "Non-Parametric Regression with Bayesx: A Flexible Estimation of Trends in Human Physical Stature in 19th Century America." Economics and Human Biology 1(1): 77-89.

Lavy, Victor and Et Al. (1996). "Quality of Health Care, Survival and Health Outcomes in Ghana." Journal of Health Economics 15(3): 333-357.

Leunig, Timothy and Hans-Joachim Voth (1998). "Smallpox Did Reduce Height: A Reply to Our Critics." Economic History Review 51(2): 372-81.

Leunig, Timothy and Hans-Joachim Voth (2001). "Smallpox Really Did Reduce Height: A Reply to Razzell." Economic History Review 54(1): 110-14.

Leunig, Timothy and Hans-Joachim Voth (2006). "Comment on 'Seat of Death and Terror'." Economic History Review 59(3): 607-16.

Linares, Claudia and Dejun Su (2005). "Body Mass Index and Health among Union Army Veterans: 1891-1905." Economics and Human Biology 3(3): 367-87.

Lintsi, Mart and Helje Kaarma (2006). "Growth of Estonian Seventeen-Year-Old Boys During the Last Two Centuries." Economics and Human Biology 4(1): 89-103.

Logan, Trevon (2006). "Food, Nutrition, and Substitution in the Late Nineteenth Century." Explorations in Economic History 43(3).

Lopez-Alonso, M. (2007). "Growth with Inequality: Living Standards in Mexico, 18501950." Journal of Latin American Studies 39: 81-105.

Lopez-Alonso, Moramay and Raul Porras Condey (2003). "The Ups and Downs of Mexican Economic Growth: The Biological Standard of Living and Inequality, 1870-1950." Economics and Human Biology 1(2): 169-186.

López-Casasnovas, Guillem, Berta Rivera, et al. (2005). Health and Economic Growth : Findings and Policy Implications. Cambridge, MIT Press.

Louw, G. J. and Maciej Henneberg (1997). "Lack of a Secular Trend in Adult Stature in White South African Males Born between 1954 and 1975." Homo - Journal of Comparative Human Biology 48(1): 54-61.

Lundberg, Shelly (2005). "Sons, Daughters, and Parental Behaviour." Oxford Review of Economic Policy 21(3).

Mahal, Ajay and Anup K. Karan (2008). "Adequacy of Dietary Intakes and Poverty in India: Trends in the 1990s." Economics and Human Biology 6(1): 57-74. 
Maloney, Thomas N. and Scott Alan Carson (2008). "Living Standards in Black and White: Evidence from the Heights of Ohio Prison Inmates, 1829-1913."

Economics and Human Biology 6(2): 237-51.

Martinez-Carrion, Jose. M. and J. Moreno-Lazaro (2007). "Was There an Urban Height Penalty in Spain, 1840-1913?" Economics and Human Biology 5(1): 144-164.

Meisel, Adolfo and Margarita Vega (2007). "The Biological Standard of Living (and Its Convergence) in Colombia, 1870-2003." Economics and Human Biology 5(1): 100-122.

Meng, Xin, Xiaodong Gong, et al. (2009). "Impact of Income Growth and Economic Reform on Nutrition Availability in Urban China: 1986-2000." Economic Development and Cultural Change 57(2): 261-295.

Meyer, Haakon E. and Randi Selmer (1999). "Income, Educational Level and Body Height." Annals of Human Biology 26(3): 219-227.

Mironov, Boris N. (1999a). "New Approaches to Old Problems: The Well-Being of the Population of Russia from 1821 to 1910 as Measured by Physical Stature." Slavic Review 58(1): 1-26.

Mironov, Boris N. (1999b). "Tall Requirements And "Small" Reality." Slavic Review 58(1): 80-90.

Mironov, Boris N. (2005). The Burden of Grandeur: Physical and Economic Well-Being of the Russian Population in the Eighteenth Century. Living Standards in the Past: New Perspective on Well-Being in Asia and Europe. R. C. Allen, T. Bengtsson and M. Dribe. Oxford, Oxford University Press: 255-75.

Mironov, Boris N. (2007). "Birth Weight and Physical Stature in St. Petersburg: Living Standards of Women in Russia, 1980-2005." Economics and Human Biology 5(1): 123(21).

Mironov, Boris N. and Brian A'Hearn (2008). "Russian Living Standards under the Tsars: Anthropometric Evidence from the Volga." Journal of Economic History 68(3): 900-29.

Mokyr, Joel and Cormac O'Grada (1996). "Height and Health in the United Kingdom 1815-1860: Evidence from the East India Company Army." Explorations in Economic History 33(2).

Moradi, Alexander and Joerg Baten (2005). "Inequality in Sub-Saharan Africa: New Data and New Insights from Anthropometric Estimates." World Development. 33(8).

Morales, Rolando, Ana María Aguilar, et al. (2003). "Geography and Culture Matter for Malnutrition in Bolivia." Economics and Human Biology 2(3): 373-89.

Morgan, Stephen L. (2000). "Richer and Taller: Stature and Living Standards in China, 1979-1995." China Journal(44): 1-39.

Morgan, Stephen L. (2004). "Economic Growth and the Biological Standard of Living in China, 1880-1930." Economics and Human Biology 2(2): 197-218.

Morgan, Stephen L. (2009). "Stature and Economic Development in South China, 18101880." Explorations in Economic History 46(1).

Morgan, Stephen L. and Shiyung Liu (2007). "Was Japanese Colonialism Good for the Welfare of Taiwanese? Stature and the Standard of Living." China Quarterly 192: 990-1013. 
Mosk, Carl (1996). Making Health Work: Human Growth in Modern Japan. Berkeley, University of California Press.

Murray, John E. (1997). "Standards of the Present for People of the Past: Height, Weight, and Mortality among Men of Amherst College, 1834-1949." Journal of Economic History 57(3): 585-606.

Neves, Walter Alves and Maria Antonieta Costa (1998). "Adult Stature and Standard of Living in the Prehistoric Atacama Desert." Current Anthropology 39(2): 278-281.

Nicholas, Stephen and Deborah Oxley (1996). "Living Standards of Women in England and Wales, 1785-1815: New Evidence from Newgate Prison Records." Economic History Review 49(3): 591-599.

Nicholas, Stephen and Richard H. Steckel (1997). "Tall but Poor: Living Standards of Men and Women in Pre-Famine Ireland." Journal of European Economic History 26(1): 105-134.

Olds, Kelly B. (2003). "The Biological Standard of Living in Taiwan under Japanese Occupation." Economics and Human Biology 1(2): 187-206.

Osmani, Siddiq and Amartya Sen (2003). "The Hidden Penalties of Gender Inequality: Fetal Origins of III-Health." Economics and Human Biology 1(1): 105-21.

Oxley, Deborah (2003). "'the Seat of Death and Terror': Urbanization, Stunting, and Smallpox." Economic History Review 56(4): 623-56.

Oxley, Deborah (2004). "Living Standards of Women in Prefamine Ireland." Social Science History 28(2): 271-295.

Oxley, Deborah Jayne (2006). "'Pitted but Not Pittied', or Does Smallpox Make You Small?" Economic History Review 41(3): 617-35.

Padez, Christina (2002). "Stature and Stature Distribution in Portuguese Male Adults 1904-1998: The Role of Environmental Factors." American Journal of Human Biology 14(1): 39-49.

Padez, Christina (2003). "Secular Trend in Stature in the Portuguese Population (19042000)." Annals of Human Biology 30(3): 262-278.

Padez, Christina and F. Johnston (1999). "Secular Trends in Male Adult Height 19041996 in Relation to Place of Residence and Parent's Educational Level in Portugal." Annals of Human Biology 26(3): 287-298.

Pak, Sunyoung (2004). "The Biological Standard of Living in the Two Koreas." Economics and Human Biology 2(3): 511-521.

Pande, Rohini P. (2003). "Selective Gender Differences in Childhood Nutrition and Immunization in Rural India: The Role of Siblings." Demography 40(3): 395-418.

Pelletier, David L. and Edward A. Frongillo (2003). "Changes in Child Survival Are Strongly Associated with Changes in Malnutrition in Developing Countries." Journal of Nutrition 133: 107-19.

Peracchi, Franco (2008). "Height and Economic Development in Italy, 1730-1980." American Economic Review: Papers \& Proceedings 98(2): 475-81.

Persico, Nicola, Andrew Postlewaite, et al. (2004). "The Effect of Adolescent Experience on Labor Market Outcomes: The Case of Height " Journal of Political Economy 112(5): 1019-53. 
Pongou, Roland, Joshua Salomon, et al. (2006). "Health Impacts of Macroeconomic Crises and Policies: Determinants of Variation in Childhood Malnutrition Trends in Cameroon." International Journal of Epidemiology 35(3): 648-656.

Popkin, Barry and Shu Wen Ng (2007). "The Nutrition Transition in High and LowIncome Countries: What Are the Policy Lessons?" Agricultural Economics 37(s1): 199-211.

Prince, Joseph M. and Richard H. Steckel (2003). "Nutritional Success on the Great Plains: Nineteenth-Century Equestrian Nomads." Journal of Interdisciplinary History 33(3): 353-84.

Pritchett, Jonathan B. (1997). "The Interregional Slave Trade and the Selection of Slaves for the New Orleans Market." Journal of Interdisciplinary History 28(1): 57-85.

Pritchett, Jonathan B. and Herman Freudenberger (1992). "A Peculiar Sample: The Selection of Slaves for the New Orleans Market." Journal of Economic History 52(1): 109-127.

Rashad, Inas (2008). "Height, Health, and Income in the U.S., 1984-2005." Economics and Human Biology 6(1): 108-126.

Razzell, Peter (1998). "Did Smallpox Reduce Height?" Economic History Review 51(2): 351-9.

Razzell, Peter (2001). "Did Smallpox Reduce Height? A Final Comment." Economic History Review 54(1): 108-9.

Rees, R., John Komlos, et al. (2003). "Optimal Food Allocation in a Slave Economy." Journal of Population Economics 16(1): 21-36.

Riley, James C. (1994). "Height, Nutrition, and Mortality Risk Reconsidered." Journal of Interdisciplinary History 24(3): 465-492.

Rogers, Beatrice Lorge (1996). "The Implications of Female Household Headship for Food Consumption and Nutritional Status in the Dominican Republic." World Development 24(1): 113-128.

Roggero, P., V. Mangiaterra, et al. (2007). "The Health Impact of Child Labor in Developing Countries: Evidence from Cross-Country Data." American Journal of Public Health 97(2): 271-275.

Rubalcava, Luis N. and Graciela M. Teruel (2004). "The Role of Maternal Cognitive Ability on Child Health." Economics and Human Biology 2(3): 439-55.

Sahn, David E. and D.C. Stifel (2002). "Parental Preferences for Nutrition of Boys and Girls: Evidence from Africa." Journal of Development Studies 39(1): 21-45.

Salvatore, Ricardo D. (2004a). "Stature Decline and Recovery in a Food-Rich Export Economy: Argentina 1900-1934." Explorations in Economic History 41(3): 233255.

Salvatore, Ricardo D. (2004b). "Stature, Nutrition, and Regional Convergence: The Argentine Northwest in the First Half of the Twentieth Century." Social Science History 28(2): 297-324.

Salvatore, Ricardo D. (2009). "Stature Growth in Industrializing Argentina: The Buenos Aires Industrial Belt 1916-1950 " Explorations in Economic History 46(1). 
Sandberg, Lars G. and Richard H. Steckel (1997). Was Industrialization Hazardous to Your Health? Not in Sweden! Health and Welfare During Industrialization. R. H. Steckel and R. Floud. Chicago, University of Chicago Press: 127-159.

Schmidt, I.M., M.H. Jørgensen, et al. (1995). "Height of Conscripts in Europe: Is Postneonatal Mortality a Predictor?" Annals of Human Biology 22(1): 57-67.

Schneider, Ryan (1996). "Historical Note on Height and Parental Consumption Decisions." Economic Letters 50(2): 279-283.

Schultz, T. Paul (2002). "Wage Gains Associated with Height as a Form of Health Human Capital." American Economic Review 92(2): 349-353.

Schwekendiek, Daniel (2008a). "Determinants of Well-Being in North Korea: Evidence from the Post-Famine Period." Economics and Human Biology 6(3): 446-54.

Schwekendiek, Daniel (2008b). "The North Korean Standard of Living During the Famine." Social Science and Medicine 66(3): 596-608.

Senauer, Benjamin and Ana L. Kassouf (2000). "The Effects of Breastfeeding on Health and the Demand for Medical Assistance among Children in Brazil." Economic Development and Cultural Change 48(4): 719-736.

Shariff, Abusaleh and Namkee Ahn (1995). "Mother's Education Effect on Child Health: An Econometric Analysis of Child Anthropometry in Uganda." Indian Economic Review 30(2): 203-222.

Silventoinen, Karri (2003). "Determinants of Variation in Adult Body Height." Journal of Biosocial Science 35(2): 263-285.

Smith, Patricia K., Barry Bogin, et al. (2003). "Economic and Anthropological Assessments of the Health of Children in Maya Immigrant Families in the US." Economics and Human Biology 1(2): 145-60.

Sokoloff, Kenneth L. (1995). The Heights of Americans in Three Centuries: Some Economic and Demographic Implications. The Biological Standard of Living on Three Continents: Further Explorations in Anthropometric History. J. Komlos. Boulder, Westview Press: 133-150.

Solakoglu, Ebru Guven (2007). "The Net Effect of Railroads on Stature in the Postbellum Period." Research in Economic History 24: 105-117.

Steckel, Richard H. (1983). "Height and Per Capita Income." Historical Methods 16: 1-7.

Steckel, Richard H. (1986). "A Peculiar Population: The Nutrition, Health, and Mortality of American Slaves from Childhood to Maturity." Journal of Economic History 46(3): 721-741.

Steckel, Richard H. (1995a). "New Perspectives on the Standard of Living." Challenge 38(5): 12-18.

Steckel, Richard H. (1996). "Percentiles of Modern Height Standards for Use in Historical Research." Historical Methods 29(4): 157.

Steckel, Richard H. (1998). "Strategic Ideas in the Rise of the New Anthropometric History and Their Implications for Interdisciplinary Research." Journal of Economic History 58(3): 803-821.

Steckel, Richard H. (1999). "Nutritional Status in the Colonial American Economy." William and Mary Quarterly 56(1): 31-52.

Steckel, Richard H. (2000). "Diets Versus Diseases in the Anthropometrics of Slave Children: A Reply." Journal of Economic History 60(1): 247-259. 
Steckel, Richard H. (2003a). "Assessing Long-Term Trends in Health." Indicators: The Journal of Social Health 2(3): 5-23.

Steckel, Richard H. (2003b). "What Can Be Learned from Skeletons That Might Interest Economists, Historians, and Other Social Scientists?" American Economic Review 93(2): 213-220.

Steckel, Richard H. (2004). "New Light on The "Dark Ages": The Remarkably Tall Stature of Northern European Men During the Medieval Era." Social Science History 28(2): 211-229.

Steckel, Richard H. (2005a). "Health and Nutrition in Pre-Columbian America: The Skeletal Evidence." Journal of Interdisciplinary History 36(1): 1-32.

Steckel, Richard H. (2005b). Health and Nutrition in the Pre-Industrial Era: Insights from a Millennium of Average Heights in Northern Europe. Living Standards in the Past : New Perspectives on Well-Being in Asia and Europe. R. C. Allen, T. Bengtsson and M. Dribe. Oxford, Oxford University Press: 227-53.

Steckel, Richard H. (2005c). "Young Adult Mortality Following Severe Physiological Stress in Childhood: Skeletal Evidence." Economics and Human Biology 3(2): 314-28.

Steckel, Richard H. (2006). Health, Nutrition and Physical Well-Being. Historical Statistics of the United States: Millennial Edition. S. B. Carter, S. Gartner, M. R. Haineset al. New York, Cambridge University Press. 2: 499-620.

Steckel, Richard H. (2008). "Biological Measures of the Standard of Living." Journal of Economic Perspectives 22(1): 129-152.

Steckel, Richard H. and Roderick Floud (1997). Health and Welfare During Industrialization. Chicago, University of Chicago Press.

Steckel, Richard H. and Joseph M. Prince (2001). "Tallest in the World: Native Americans of the Great Plains in the Nineteenth Century." American Economic Review 91(1): 287-294.

Steckel, Richard H. and Jerome C. Rose, Eds. (2002a). The Backbone of History : Health and Nutrition in the Western Hemisphere. Cambridge ; New York, Cambridge University Press.

Steckel, Richard H. and Jerome C. Rose (2002b). Conclusions. The Backbone of History: Health and Nutrition in the Western Hemisphere. R. H. Steckel and J. C. Rose. New York, Cambridge University Press: 583-89.

Steckel, Richard. H. (1995b). "Stature and the Standard of Living." Journal of Economic Literature 33(4): 1903-1940.

Stegl, Mojgan and Joerg Baten (2009). "Tall and Shrinking Muslims, Short and Growing Europeans: The Long-Run Welfare Development of the Middle East, 1850-1980." Explorations in Economic History 46(1).

Stillman, Steven (2006). "Health and Nutrition in Eastern Europe and the Former Soviet Union During the Decade of Transition: A Review of the Literature." Economics and Human Biology 4(1): 104-46.

Stillman, Steven and Duncan Thomas (2008). "Nutritional Status During an Economic Crisis: Evidence from Russia." Economic Journal 118(531): 1385-1417.

Strauss, John (1995). "Nutrition and Poverty." Journal of Economic Literature 33(2): 860-862. 
Strauss, John and Duncan Thomas (1995). Human Resources: Empirical Modeling of Household and Family Decisions. Handbook of Development Economics. $\mathrm{H}$. Chenery and T. N. Srinivasan. 3A: 1883-2023.

Sunder, Marco (2003). "The Making of Giants in a Welfare State: The Norwegian Experience in the 20th Century." Economics and Human Biology 1(2): 267-276.

Sunder, Marco (2004). "The Height of Tennessee Convicts: Another Piece of The "Antebellum Puzzle"." Economics and Human Biology 2(1): 75-86.

Sunder, Marco (2007). Passports and Economic Development: An Anthropometric History of the US Elite in the Nineteenth Century. Munich, Ludwig-MaximiliansUniversität. Ph.D.

Sunder, Marco and Ulrich Woitek (2005). "Boom, Bust and the Human Body: Further Evidence on the Relationship between Height and Business Cycles." Economics and Human Biology 3(3): 450-66.

Svedberg, Peter (1999). "841 Million Undernourished?" World Development 27(12): 2081-2098.

Svedberg, Peter (2000). Poverty and Undernutrition--Theory, Measurement and Policy. Oxford, Oxford University Press.

Svedberg, Peter (2002). "Undernutrition Overestimated." Economic Development and Cultural Change 51(1): 5-36.

Szreter, Simon and Graham Mooney (1998). "Urbanization, Mortality, and the Standard of Living Debate: New Estimates of the Expectation of Life at Birth in NineteenthCentury British Cities." Economic History Review 51(1): 84-112.

Tadman, Michael (2000). "The Demographic Cost of Sugar: Debates on Slave Societies and Natural Increase in the Americas " American Historical Review 105(5): 153475.

Tarozzi, Alessandro and Aprajit Mahajan (2007). "Child Nutrition in India in the Nineties." Economic Development and Cultural Change 55(3): 441-86.

Tarp, Finn, Kenneth Simler, et al. (2002). "The Robustness of Poverty Profiles Reconsidered." Economic Development and Cultural Change 51(1): 77-108.

Tatarek, Nancy E. (2006). "Geographic Height Variation among Ohio Caucasian Male Convicts Born 1780-1849." Economics and Human Biology 4(2).

Thomas, Duncan, Victor Lavy, et al. (1996). "Public Policy and Anthropometric Outcomes in the Côte d'Ivoire." Journal of Public Economics 61(2): 155-92.

Thomas, Duncan and John Strauss (1997). "Health and Wages: Evidence on Men and Women in Urban Brazil (Analysis of Data on Health)." Journal of Econometrics 77(1): 159-86.

Turrell, Gavin (2002). "Socio-Economic Position and Height in Early Adulthood." Australian \& New Zealand Journal of Public Health 26(5): 468-472.

Twarog, Sophia (1997). Heights and Living Standards in Germany, 1850-1939: The Case of Wurttemberg. Health and Welfare During Industrialization. R. H. Steckel and R. Floud. Chicago, University of Chicago Press: 285-330.

Valdivia, Martín (2004). "Poverty, Health Infrastructure and the Nutrition of Peruvian Children." Economics and Human Biology 2(3): 489-510. 
Vecchi, Giovanni and Michela Coppola (2006). "Nutrition and Growth in Italy, 18611911: What Macroeconomic Data Hide." Explorations in Economic History 43(3): 438-464.

Vignerová, J., M. Brabec, et al. (2006). "Two Centuries of Growth among Czech Children and Youth." Economics and Human Biology 4(2): 237-52.

Voss, L.D., J. Mulligan, et al. (1998). "Short Stature at School Entry as an Index of Social Deprivation? (the Wessex Growth Study)." Child: Care, Health \& Development 24(2): 145-156.

Voth, Hans-Joachim (1995). "Height, Nutrition, and Labor: Recasting The "Austrian Model"." Journal of Interdisciplinary History 25(4): 627-636.

Voth, Hans-Joachim (1996). "Physical Exertion and Stature in the Habsburg Monarchy, 1730-1800." Journal of Interdisciplinary History 27(2): 263-275.

Voth, Hans-Joachim and Timothy Leunig (1996). "Did Smallpox Reduce Height? Stature and the Standard of Living in London, 1770-1873." Economic History Review 49(3): 541-560.

Wada, Roy and Erdal Tekin (2007). Body Composition and Wages NBER Working Paper No. 13595. Cambridge.

Webb, Elizabeth Alice, Diana Kuh, et al. (2008). "Estimation of Secular Trends in Adult Height, and Childhood Socioeconomic Circumstances in Three Eastern European Populations." Economics and Human Biology 6(2): 228-236.

Webb, Patrick and Steven Block (2004). "Nutrition Information and Formal Schooling as Inputs to Child Nutrition." Economic Development and Cultural Change 52(4): 801-820.

Weil, David N. (2007). "Accounting for the Effect of Health on Economic Growth." Quarterly Journal of Economics 122(3): 1265-1306.

Weir, David R. (1997). Economic Welfare and Physical Well-Being in France, 17501990. Health and Welfare During Industrialization. R. H. Steckel and R. Floud. Chicago, University of Chicago Press: 161-200.

Wheatcroft, Stephen George (1999). "The Great Leap Upwards: Anthropometric Data and Indicators of Crises and Secular Change in Soviet Welfare Levels, 18801960." Slavic Review 27(1): 27-60.

Wheatcroft, Stephen George (2009). "The First Thirty Five Years of Soviet Living Standards: Secular Growth and Conjunctural Crises in a Time of Famine." Explorations in Economic History 46(1).

Whitwell, Greg, Christine De Souza, et al. (1997). Height, Health, and Economic Growth in Australia, 1860-1940. Health and Welfare During Industrialization. R. H. Steckel and R. Floud. Chicago, University of Chicago Press: 379-422.

Whitwell, Greg and Stephen Nicholas (2001). "Weight and Welfare of Australians, 18901940." Australian Economic History Review 41(2): 159-175.

WHO (2001). Macroeconomics and Health: Investing in Health for Economic Development. Geneva, World Health Organization.

Wilk, Richard (1999). "Quality of Life and the Anthropological Perspective." Feminist Economics 5(2): 91-93.

Woitek, Ulrich (2003). "Height Cycles in the 18th and 19th Centuries." Economics and Human Biology 1(2): 243-57. 
Yamauchi, Futoshi (2008). "Early Childhood Nutrition, Schooling, and Sibling Inequality in a Dynamic Context: Evidence from South Africa." Economic Development and Cultural Change 56(3): 657-682. 


\section{Endnotes}

${ }^{1}$ The 1995 review omitted a few publications. The current effort attempts to be more comprehensive within the boundaries noted in the introduction. Books and papers in edited collections are more difficult than journal articles to interrogate electronically and unfortunately some of these were probably missed, especially if they made occasional reference to stature. 